\title{
A New Frontier: Applying Evolving National Pay Equity Trends to Kansas's Statute
}

\author{
Sangeeta Shastry Kleinmann*
}

\section{INTRODUCTION}

In June 2016, an employee of a restaurant called Pizza Studio in Kansas City, Kansas, asked why she was earning twenty-five cents less than her friend, a male coworker. ${ }^{1}$ Seventeen-year-old Jensen Walcott discussed her $\$ 8$ per hour salary with Jake Reed, also seventeen, who earned $\$ 8.25$ per hour but had the same responsibilities and experience level as Walcott. ${ }^{2}$ Walcott spoke with a manager, who fired her and cited a company policy prohibiting wage discussions as the rationale. ${ }^{3}$ Though the restaurant eventually fired the manager and apologized, Walcott's story caught the eye of local and national media. ${ }^{4}$ She and Reed became the focus of policy arguments during the 2016 presidential election. ${ }^{5}$

As Walcott's story gained national attention, it cast Kansas's current pay equity statute into stark relief. The law, in existence for 39 years, ${ }^{6}$ has fallen behind the trend of other states' legislation that is developing a different approach to pay equity laws nationwide. Subsequently, the pay gap between men and women in Kansas has persisted. ${ }^{7}$ The state's

\footnotetext{
* Law student and Kansas Law Review Articles Editor, University of Kansas School of Law, Lawrence, Kansas. Many thanks are due to Professor Lua Yuille for her guidance in researching and writing this Comment and to the entire staff of the Kansas Law Review for their feedback and editing.

1. Lisa Gutierrez, Teen's Wage Disparity at KCK Pizza Shop Fires up Equal-Pay Debate and Hillary Clinton, THE KANSAS CITY STAR (June 27, 2016, 1:15 PM), http://www.kansascity.com/news/local/article86226237.html.

2. Id.

3. Id.

4. Id. See also Seth Stevenson, How to Write a Convention Speech for Two Anxious Teenagers, SLATE (July 28, 2016, $2: 32 \quad$ PM), http://www.slate.com/articles/news_and_politics/politics/2016/07/how_the_dnc_wrote_the_speech_f or_jensen_walcott_and_jake_reed.html.

5. Gutierrez, supra note 1.

6. KAN. Stat. ANN. § 44-1205 (West 2000).

7. National Partnership for Women \& Families, Kansas Women and the Wage Gap (Apr.
} 
continuing wage disparity is a microcosm of the national pay inequity problem. ${ }^{8}$ Although iterations of federal pay equity laws have been in place for more than 70 years, women over age 35 still only earn between $76 \%$ and $81 \%$ of wages men earn, and even within the demographic with the smallest wage disparities - workers under the age of 35-women still earned $8 \%$ to $10 \%$ less than men do. ${ }^{9}$ This data, paired with Walcott's experience, provides an apt prologue to the central thesis developed in this Comment: To make substantial efforts to close its wage gap, Kansas - and other states facing similar wage disparity problemsshould follow models set out by three states that have strengthened provisions in their pay equity statutes. These provisions address employer justifications for wage discrepancies and anti-retaliation measures, as well as expand the bases on which employees can file wage discrimination claims.

These three states-California, Massachusetts, and New Yorkpassed legislation that aims to strengthen protections for workers and gives teeth to employee wage discrimination suits. ${ }^{10}$ These states' approaches to closing the wage gap serve as models from which Kansas and other states can draw language and provisions to address their longstanding pay equity problems. For example, these statutes raise the bar employers must meet when providing explanations for wage discrepancies between female and male employees that are not based on sex. ${ }^{11}$ The laws include protections for employees who want to discuss their wages with one another and with their employers. ${ }^{12}$ The statutes also broaden the geographic scope employees can use to compare themselves to others to demonstrate wage disparities. ${ }^{13}$ Kansas's statute falls far short of California, Massachusetts, and New York's pay equity provisions. The Kansas law does not include analogous provisions about wage discussions or retaliation, and the scope of comparisons employees can make when filing suit are narrower. ${ }^{14}$

\footnotetext{
2016), http://www.nationalpartnership.org/research-library/workplace-fairness/fair-pay/4-2016-kswage-gap.pdf (noting that Kansas women earn on average 77 cents for every dollar Kansas men earn).

8. U.S. Bureau of Labor Statistics, Highlights of Women's Earnings in 2014, BLS REPORTS 2 (Nov. 2015), http://www.bls.gov/opub/reports/womens-earnings/archive/highlights-of-womensearnings-in-2014.pdf'.

9. Id.

10. See infra Part II.B.3.

11. Id.

12. Id.

13. Id.

14. See infra Part II.B.2.
} 
There is an overarching social justice argument in favor of strengthening Kansas's pay equity statute: employers should not compensate women and men engaged in comparable work differently. Regardless, states and businesses have taken issue with the economic impact that expanded pay equity laws may have. ${ }^{15}$ These concerns necessitate an economic approach to advocating for stronger pay equity laws that supports the social justice argument.

This Comment argues that Kansas should incorporate select provisions from federal statutes and proposed legislation as well as from California, Massachusetts, and New York's laws. Such adoptions would have positive economic consequences for not only Kansas women, but also for the state as a whole. Part II provides a primer on current federal and state pay equity statutes and focuses on comparisons and shortcomings among California, Massachusetts, and New York's new statutes. This section also compares Kansas's current pay equity law to the three aforementioned updated statutes. Part III aims to accomplish two tasks to make the argument that Kansas would economically benefit from adopting a combination of strengthened pay equity statutory provisions. First, this section outlines the economic context and positive economic contributions such provisions would make in Kansas. Second, this section explains the specific provisions Kansas should adopt and the impact such changes will have on empowering employees to seek pay equity and addressing economic policy concerns arising from the persistent wage gap.

\section{DEVELOPMENT AND LiMITATIONS OF CURRENT LAW}

While federal and state pay equity laws date back to the mid-20th century, they have provided insufficient protection for workers, primarily women, who continue to face broad wage inequality. The Fair Labor Standards Act, which "establishe[d] minimum wage, overtime pay, recordkeeping[,] and child labor standards,"

\footnotetext{
15. See, e.g., Samantha Marcus, Christie Vetoes N.J. Equal Pay Bill, NJ.COM http://www.nj.com/politics/index.ssf/2016/05/christie_announces_partial_veto_of_equal_

pay_bill.html (last updated May 4, 2016, 2:44 AM) (noting that Governor Christie vetoed the state's pay equity bill in part because he found it to be "business unfriendly"); Diana Furchtgott-Roth, The Pay-Equity Police Get New Ammunition, WALl ST. J. (Apr. 11, 2016, 7:15 PM), http://www.wsj.com/articles/the-pay-equity-police-get-new-ammunition-1460416530 (arguing that strengthened pay equity statutes would result in heightened business costs).

16. Rosa Cho \& Abagail Kramer, Everything You Need to Know About the Equal Pay Act, INT'L CENTER FOR RES. ON WOMEN 3, https://www.icrw.org/wpcontent/uploads/2016/11/Everything-You-Need-to-Know-about-the-Equal-Pay-Act.pdf (last visited Mar. 27, 2017).
} 
half-century's legislation governing the wage gap between men and women. ${ }^{17}$ As this section will first discuss, the subsequent Equal Pay Act of 1963, Title VII of the 1964 Civil Rights Act, and the Lilly Ledbetter Fair Pay Act, among other statutes, substantially shaped the landscape of federal pay equity law. ${ }^{18}$ Many state pay equity statutes retain the core language found in these federal laws. The second part of this section provides an overview of Kansas' statutory language, which has drawn from federal pay equity statutes. Finally, the third part of this section surveys the recently updated California, Massachusetts, and New York statutes and their substantial alterations made to existing provisions. ${ }^{19}$ Categorizing state pay equity statutes and comparing those categories to California, Massachusetts, and New York's statutory provisions prove helpful in highlighting how far those three states have pushed the frontier of state pay equity laws - and the ways in which those statutes, as well as Kansas's law, have fallen short.

\section{A. Overview of Federal Pay Equity Statutes}

A survey of the history, provisions, and shortcomings of federal pay equity statutes provides a framework to understand the scope of state pay equity statutes that draw from federal law. The evolution of federal pay equity law-including those bills Congress failed to pass-has produced legislative models from which to craft statutes aimed to be more effective in closing the wage gap than federal and state laws in effect. This section discusses the effective provisions and limitations of the Equal Pay Act, Title VII of the 1964 Civil Rights Act, the proposed Paycheck Fairness Act that Congress did not enact, and the Lilly Ledbetter Fair Pay Act.

\section{Early Attempts and the Equal Pay Act}

Initiatives to enact statutory pay equity provisions at the state and federal level in the United States began as early as $1944 .^{20}$ That year, a bill introduced in the House of Representatives would have prohibited

17. See M. Neil Browne \& Michael D. Meuti, Individualism and the Market Determination of Women's Wages in the United States, Canada, and Hong Kong, 21 LOY. L.A. INT'L \& COMP. L.J. 355, 365 (1999) (noting that "attempts at pay equity legislation in the United States date back to the early years of the twentieth century"). See also Cho \& Kramer, supra note 16, at 2-5 (providing a timeline of major federal pay equity legislation in the United States).

18. See Browne \& Meuti, supra note 17 , at $365-72$; Cho \& Kramer, supra note 16 , at 2-5 (outlining the timeline of federal pay equity statutes enacted in the United States).

19. See infra Part II.B.3.

20. See H.R. 5056, 78th Cong. (1944). 
"[d]iscrimination against employees, in rates of compensation paid, on account of sex." ${ }^{21}$ In 1945, Congress introduced legislation proposing women be compensated equally for "comparable work" - a standard that would cause controversy more than four decades later. ${ }^{22}$ While neither piece of legislation passed, every Congress from 1945 until 1981 introduced bills requiring equal pay for "comparable work." 23

These attempts to shrink the wage gap led to a watershed moment almost twenty years later, when Congress incorporated the landmark federal Equal Pay Act of 1963 into the Fair Labor Standards Act. ${ }^{24}$ The Equal Pay Act created the right for employees "within any establishment" to receive equal wages for "equal work on jobs the performance of which requires equal skill, effort, and responsibility, and which are performed under similar working conditions ...."25 A plaintiff bringing a claim under the law bears the initial burden of demonstrating a wage disparity. ${ }^{26}$ The burden then shifts to the employer to demonstrate one of four affirmative defenses: "(i) a seniority system"“; (ii) a merit system"“; (iii) a system which measures earnings by quantity or quality of production"“; or (iv) a differential based on any other factor other than sex."27 The statute prohibits employers from decreasing wages to comply with its provisions. ${ }^{28}$ Damages under the federal statute include unpaid minimum wages or unpaid overtime compensation, as well as "an additional equal amount as liquidated damages." 29 Separate fines of up to $\$ 1,100$ result if plaintiffs can prove employers willfully violated the law. ${ }^{30}$ Penalties are determined in part by business sizes and the seriousness of violations. ${ }^{31}$

21. Id

22. See also Elizabeth J. Wyman, The Unenforced Promise of Equal Pay Acts: A National Problem and Possible Solution from Maine, 55 ME. L. REV. 23, 24 n.5 (2003) (noting that "[t]he first bill proposing equal pay for women doing "ccomparable work" as men was introduced in 1945").

23. Cty. of Wash. v. Gunther, 452 U.S. 161, 185 n.1 (1981).

24. Wyman, supra note 22 , at 30.

25. 29 U.S.C. $§ 206(d)(1)$ (2012); Wyman, supra note 22, at 30.

26. Wyman, supra note 22 , at 32 .

27. 29 U.S.C. $\$ 206(d)(1)$ (2012); Wyman, supra note 22, at 31.

28. 29 U.S.C. $\$ 206(d)(1)(2012)$.

29. Id. $\S 216(\mathrm{~b})$. However, the Sixth Circuit in the 2014 case Michigan Corrections Organization v. Michigan Department of Corrections held that a state "does not violate the Privileges or Immunities Clause by denying the minimum-wage or overtime-pay requirement established by Congress in the [Fair Labor Standards Act]" and further held that pursuant to the Fourteenth Amendment, Congress could not authorize private rights of action against states brought under the Fair Labor Standards Act. Mich. Corr. Org. v. Mich. Dep't of Corr., 774 F.3d 895, 90102 (6th Cir. 2014).

30. Id. §216(e)(2).

31. Id. $\S 216(\mathrm{e})(3)$. 
Despite the Equal Pay Act's status as a milestone, however, the "equal pay for equal work" definition left quite a bit of room for employers to develop seemingly non-pretextual reasons to explain compensation differences between male and female employees. ${ }^{32}$ To allow for wage discrepancies, employers would "only need to alter a job description along only one of the four axes used for measuring value to make a 'man's job' different from a similar 'woman's job," thereby precluding a claim. ${ }^{33}$ There is also "little guidance" ${ }^{34}$ governing the somewhat-ambiguous $^{35}$ work equality standard, rendering plaintiff successes under the Equal Pay Act relatively rare compared to outcomes of claims filed under other pay equity laws. ${ }^{36}$

2. Title VII and the Paycheck Fairness Act: Broadening Pay Equity Law

The Equal Pay Act was only the start of federal legislation that attempted to close the wage gap between men and women: shortly thereafter, Congress enacted Title VII of the 1964 Civil Rights Act, which further protected employees from discrimination on the basis of sex, among other characteristics. ${ }^{37}$ More than 40 years later, Congress took up another significant bill on the pay equity landscape: the Paycheck Fairness Act, ${ }^{38}$ which, if passed, would have aligned federal pay equity law more closely with the provisions of California, Massachusetts, and New York's strengthened statutes. Title VII and the Paycheck Fairness Act addressed - or would have addressed-some of the Equal Pay Act's shortcomings, but Title VII in particular still placed a heavy burden on plaintiffs bringing wage discrimination claims.

32. Browne \& Meuti, supra note 17, at 366. See also Wyman, supra note 22, at 31, 34 (noting that "the federal courts have interpreted the EPA narrowly, holding plaintiffs to a high burden of proof" and that "despite the admonition contained in the federal regulations that insubstantial differences' should not prevent a finding of equal work, the courts have not 'reach[ed] beyond comparisons of virtually identical jobs, which in a workforce substantially segregated by gender, provides women with a very limited substantive right indeed"').

33. Browne \& Meuti, supra note 17 , at 366.

34. Wyman, supra note 22 , at 33.

35. See Wyman, supra note 22, at 33 (noting that the Code of Federal Regulations "admit[s] that 'what constitutes equal skill, equal effort, or equal responsibility cannot be precisely defined,' although the section goes on to state that interpretation of these key terms must be done with consideration for the "broad remedial purpose of the law"').

36. Wyman, supra note 22 , at 33.

37. 42 U.S.C. $\S 2000 \mathrm{e}-2(\mathrm{a})(1)$ (2012).

38. S. 841, 109th Cong. (2005). 
Title VII broadened employees' abilities to bring claims beyond what was possible under the Equal Pay Act. ${ }^{39}$ Though "the federal courts have interpreted the [Equal Pay Act] narrowly," one federal district court noted that Title VII " "requires a less-exacting degree of job similarity than is necessary to bring an [Equal Pay Act] action." ${ }^{40}$ In part, Title VII prohibits discrimination based on "race, color, religion, sex, or national origin" in employment, specifically with regard to employees' "compensation, terms, conditions, or privileges of employment." "41 To bring a claim under Title VII, a plaintiff must demonstrate that the defendant "uses a particular employment practice that causes a disparate impact on the basis of race, color, religion, sex, or national origin" and "fails to demonstrate that the challenged practice is job related for the position in question and consistent with business necessity." 42 Congress separately amended the statute to incorporate the affirmative defenses of the Equal Pay Act: seniority, merit, quantity or quality of production, and factors other than sex. ${ }^{43}$ This modification, called the Bennett Amendment, sought to address the concern that plaintiffs would be able to bring claims under Title VII without being beholden to the Equal Pay Act's "equal pay for equal work" standard. ${ }^{44}$ Title VII does exempt wage differentials between "employees who work in different locations" as well as discrepancies that are "not the result of an intention to discriminate because of race, color, religion, sex, or national origin." 45

Title VII did continue to pose challenges for plaintiffs, however. The "difficulty of proving discrimination in a Title VII case" continued to create problems - and perpetuate relatively low success rates-for plaintiffs seeking to file under this statute as opposed to the Equal Pay Act. ${ }^{46}$ Courts narrowly construed the "disparate impact" plaintiffs must demonstrate to include only "cases that challenge a specific, clearly delineated employment practice applied at a single point in the job selection process," not broad wage disparities between male and female employees in jobs dominated by employees of one sex. ${ }^{47}$ This limited

\footnotetext{
39. Wyman, supra note 22, at 32-33; Browne \& Meuti, supra note 17, at 367-68.

40. Wyman, supra note 22, at 31-33.

41. 42 U.S.C. $\S 2000 \mathrm{e}-2(\mathrm{a})(1)(2012)$.

42. $I d . \S 2000 \mathrm{e}-2(\mathrm{k})(1)(\mathrm{A})(\mathrm{i})$.

43. Id. $\S 2000 \mathrm{e}-2(\mathrm{~h})$. See also Wyman, supra note 22, at 31-32.

44. 42 U.S.C. $\S 2000 \mathrm{e}-2$ (h) (2012). See also Wyman, supra note 22, at 32 (noting that "[i]n County of Washington v. Gunther, the Supreme Court held that the Bennett Amendment did not import the "equal pay for equal work" standard into Title VII").

45. 42 U.S.C. $\S 2000 \mathrm{e}-2(\mathrm{~h})(2012)$.

46. Wyman, supra note 22, at 33 .

47. Browne \& Meuti, supra note 17, at 370.
} 
plaintiffs' abilities to challenge institutional wage discrimination simply because a field had been controlled by workers of the opposite sex. Plaintiffs' burdens of proof also differ between Title VII and the Equal Pay Act: under Title VII, plaintiffs "maintain[] the burden of proof throughout the case, with the employer only having to set forth a plausibly nondiscriminatory reason for engaging in the conduct that has been alleged to be discriminatory." 48 Title VII also requires plaintiffs to show employers' discriminatory intent. ${ }^{49}$

Analogous to the buildup of equal pay efforts that culminated in the Equal Pay Act, significant attempts at pay equity legislation predated the 2009 law. Among the most significant was the 2005 Paycheck Fairness Act, introduced by then-Senator Hillary Clinton of New York and Representative Rosa DeLauro of Connecticut. ${ }^{50}$ Had Congress enacted it, the bill would have moved federal pay equity law closer to the boundaries recently created by California, Massachusetts, and New York. $^{51}$ Regardless, the bill helped lay the groundwork for the Lilly Ledbetter Fair Pay Act, the third major statutory development in the federal pay equity landscape that President Barack Obama signed into law in 2009. ${ }^{52}$

The Paycheck Fairness Act sought to amend the Fair Labor Standards Act - just as the Equal Pay Act had done-and incorporate "nonretaliation provisions, enhance penalties, and allow the Secretary of Labor ... to pursue compensatory or punitive damages." would have bolstered the "factor other than sex" affirmative defense incorporated into the Equal Pay Act and Title VII. ${ }^{54}$ It would have required employers to demonstrate that pay differentials resulted from "education, training[,] or experience." 55 The bill also would have only allowed employers to use this affirmative defense if the factor was "jobrelated" or "further[ed] a legitimate business purpose," unless the employee could show that an alternative practice would serve that purpose without creating a wage differential and that the employer

\footnotetext{
48. Wyman, supra note 22, at 32.

49. See Ledbetter v. Goodyear Tire \& Rubber Co., 550 U.S. 618, 640 (2007) (noting that the Equal Pay Act "does not require the filing of a charge with the EEOC or proof of intentional discrimination" because the statute asks "only whether the alleged inequality resulted from "any other factor other than sex"').

50. S. 841, 109th Cong. (2005). See also Cho \& Kramer, supra note 16, at 4.

51. See infra Part II.B.3.

52. S. 181, 111th Cong. (2009).

53. S. 841, 109th Cong. (2005).

54. See id. §3(a).

55. Id.
} 
refused to adopt the alternative practice. ${ }^{56}$ To have a valid defense, employers needed to apply such factors reasonably. ${ }^{57}$ The bill also would have prohibited employers from reducing employees' wages to comply with its provisions. ${ }^{58}$

The Paycheck Fairness Act would have granted greater employee protections by eliminating the "establishment requirement" Equal Pay Act. ${ }^{60}$ That requirement only allowed employees bringing claims under the Equal Pay Act to compare their salaries to others working within the same establishment. ${ }^{61}$ Deleting the "establishment" requirement would have amended the Equal Pay Act provisions that prohibited employers from "discriminat[ing], within any establishment in which ... employees are employed, between employees on the basis of sex." ${ }^{62}$ This modification would have broadened the scope within which employees could compare themselves to other employees to demonstrate pay disparities. ${ }^{63}$

Further, the bill would have prohibited employers from retaliating against employees because they "inquired about, discussed, or otherwise disclosed the wages of the employee or another employee, or because [they have] made a charge, testified, assisted, or participated in any manner in an investigation, proceeding, hearing, or action." ${ }^{64}$ Such a non-retaliation provision only exists as "part of the broader wage and hour protections of the Fair Labor Standards Act" with respect to the Equal Pay Act, and does not provide protections from retaliation as broad as those the Paycheck Fairness Act would have offered. ${ }^{65}$ The Paycheck Fairness Act would also have amended the Fair Labor Standard Act's damages provisions and enabled the Secretary of Labor to seek additional damages. ${ }^{66}$ Plaintiffs would have been able to recover not only unpaid minimum wages and overtime compensation as well as

\footnotetext{
56. Id. §3(a)(I)(aa).

57. Id. §3(a)(I)(bb).

58. Id. $\S 3(\mathrm{a})(\mathrm{II})$.

59. Id. $\S 3(\mathrm{c})(1)-(2)$.

60. Id. $\S 3(\mathrm{c})(1)-(2), 3(\mathrm{~d})$.

61. See infra Part II.A.1.

62. 29 U.S.C. $§ 206(d)(1)$ (2012) (emphasis added).

63. See S. 841, 109th Cong. § 3(c) (2005) (eliminating the requirement for employees bringing wage disparity claims to demonstrate the statutory element of discrimination between or among employees at the same establishment).

64. Id. $\S 3(\mathrm{~d})(2)$.

65. 29 U.S.C. $§ 206$; Laura S. Schnell \& Peter A. Basso, Proving Retaliation Under FEDERAL NON-DISCRIMINATION STATUTES http://www.americanbar.org/content/dam/aba/administrative/labor_law/meetings/2011/ac2011/041.a uthcheckdam.pdf.

66. S. 841, 109th Cong. § 3(e) (2005).
} 
liquidated damages, but also compensatory and punitive damages from their employers. ${ }^{67}$ The bill would have authorized the Secretary of Labor to seek compensatory and punitive damages. ${ }^{68}$ The bill's sponsors categorized the increased damages and non-retaliation provision as "[e]nhanced enforcement of equal pay requirements." recognized the need for such provisions because of "lingering effects of past discrimination" that persisted in preventing women from achieving pay equity, despite women "enter[ing] the workforce in record numbers" for half a century before the bill's introduction, roughly since the passage of the Equal Pay Act and Title VII. ${ }^{70}$

\section{Lilly Ledbetter Fair Pay Act: Jurisprudential and Statutory Shifts}

Four years after the Paycheck Fairness Act failed to clear Congress, President Obama signed the Lilly Ledbetter Fair Pay Act into law. ${ }^{71}$ The statute clarified when the statute of limitations on a Title VII wage discrimination claim begins to run and strengthened damages available for such claims. Congress passed the law in reaction to a United States Supreme Court case, Ledbetter v. Goodyear Tire \& Rubber Co., involving the woman at the center of the eponymous legislation. ${ }^{72}$ The issues in the case were the timeliness of Lilly Ledbetter's disparate impact claim and whether her employer had acted with discriminatory intent. $^{73}$ Ledbetter alleged her employer's performance reviews discriminated against her because of her sex and that as a result, she received lower pay compared to her male colleagues. ${ }^{74}$ Ledbetter filed a complaint with the Equal Employment Opportunity Commission (EEOC) in $1998 .^{75}$

The statute of limitations applied to Ledbetter's claims depended upon the Court's interpretation of the discriminatory "discrete act" Title

67. Id. §3(e)(1) (providing, however, that the United States as an employer would not be held liable for punitive damages).

68. $I d . \S 3(\mathrm{f})$.

69. Id. $\S 3$.

70. Id. § 2(1)-(2).

71. Lilly Ledbetter Fair Pay Act, S. 181, 111th Cong. (2009).

72. Ledbetter v. Goodyear Tire \& Rubber Co., 550 U.S. 618 (2007).

73. Id. at 623 (noting that Ledbetter filed a writ of certiorari to resolve the issue of "[w]hether and under what circumstances a plaintiff may bring an action under Title VII of the Civil Rights Act of 1964 alleging illegal pay discrimination when the disparate pay is received during the statutory limitations period, but is the result of intentionally discriminatory pay decisions that occurred outside the limitations period").

74. Id. at $621-22,643$.

75. Id. at 621-22. 


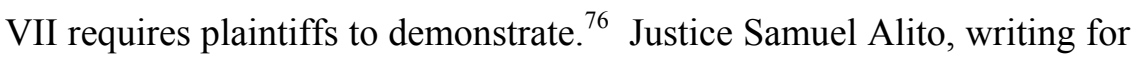
the majority, noted Ledbetter alleged each amount she was paid was "unlawful" because her wages would have been higher had she not faced discrimination in her evaluations before filing her EEOC complaint. ${ }^{77}$ The Court, however, held that Ledbetter should have filed her claim within 180 days - the Title VII statute of limitations - of a single discriminatory act: when Goodyear issued Ledbetter's paychecks after her EEOC complaint, for example, or when Goodyear denied Ledbetter a raise in $1998 .^{78}$ Justice Alito noted that while an employer could violate Title VII several times by taking several separate, intentionally discriminatory actions, a single discriminatory act followed by a series of nondiscriminatory acts producing "adverse effects" from the discrimination would not constitute several separate violations. ${ }^{79}$ The Court also found Ledbetter had not demonstrated that Goodyear acted with an intent to discriminate against her on the basis of her sex, as required by Title VII. ${ }^{80}$ Further, even if Ledbetter had shown intent, the Court found her "attempt to take the intent associated with the prior pay decisions and shift it to the 1998 pay decision" to be improper. ${ }^{81}$

Justice Ruth Bader Ginsburg, writing for the dissent, highlighted the practical difficulties of complying with the standard set out by the majority-and the statute itself. "Pay disparities," Justice Ginsburg wrote, "often occur, as they did in Ledbetter's case, in small increments; cause to suspect that discrimination is at work develops only over time." ${ }^{\prime 2}$ Employers might not disclose any information about wage differentials, further hindering notice to a potential plaintiff. ${ }^{83}$ Employment decisions such as "promotions, transfers, hirings, and firings" allow employees to "immediately seek out an explanation and evaluate it for pretext." "Compensation disparities"-particularly those resulting from male employees receiving larger pay raises than female employees - "are often hidden from sight," Justice Ginsburg wrote. ${ }^{85}$ The dissent noted that a plaintiff's "initial readiness to give her employer the benefit of the doubt should not preclude her from later challenging

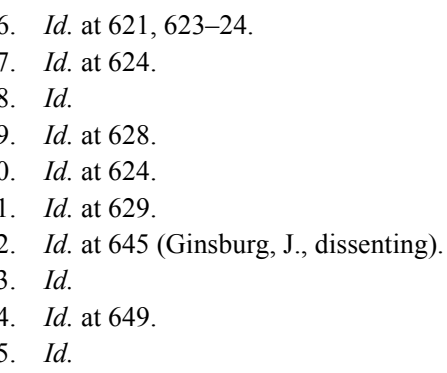


the then current and continuing payment of a wage depressed on account of her sex." $" 86$

Congress subsequently passed the Lilly Ledbetter Fair Pay Act to amend Title VII. ${ }^{87}$ The Act redefined the occurrence of a discriminatory employment practice as instances in which an employer adopts a "discriminatory compensation decision or other practice," when an employee "becomes subject" to that type of decision or practice, or when an employee is affected by such a decision or practice. ${ }^{88}$ These decisions and practices include each instance of employers paying wages or other compensation resulting from discriminatory decisions. ${ }^{89}$ Further, prevailing plaintiffs can recover up to two years' back pay that accrued before they filed their claims if the unlawful practices "are similar or related to" the practices that occurred after plaintiffs filed their claims. ${ }^{90}$

Critics of the Lilly Ledbetter Fair Pay Act have deemed it both overbroad and not broad enough. ${ }^{91}$ Most pertinent to the arguments in this Comment are critiques that the Act does not provide enough protection for workers; namely, the law is silent on pay confidentiality policies many employers have in place. ${ }^{92}$ By failing to even address employees who discuss their wages, the Act ignores the very reason prospective plaintiffs could bring wage discrimination claims: determining whether a wage discrepancy exists. ${ }^{93}$ Conversely, some view the Act as creating expansive exceptions to statutes of limitations that could infringe on employers' rights to notice of potential claims,

86. Id. at 645 .

87. Lilly Ledbetter Fair Pay Act, S. 181, 111th Cong. (2009) (Congress found that Ledbetter "significantly impair[ed] statutory protections against discrimination in compensation that Congress established and that have been bedrock principles of American law for decades" and "unduly restrict[ed] the time period in which victims of discrimination can challenge and recover for discriminatory compensation decisions or other practices, contrary to the intent of Congress." Congress echoed Justice Ginsburg's dissent and noted that the decision "ignores the reality of wage discrimination and is at odds with the robust application of the civil rights laws that Congress intended.").

88. Id.; 42 U.S.C. $\S 2000 \mathrm{e}-5(\mathrm{e})(3)(\mathrm{A})(2012)$.

89. 42 U.S.C. $\S 2000 \mathrm{e}-5(\mathrm{e})(3)(\mathrm{A})(2012)$.

90. Lilly Ledbetter Fair Pay Act, S. 181, 111th Cong. § 3 (2009); 42 U.S.C. § 2000e$5(\mathrm{e})(3)(\mathrm{B})(2012)$.

91. See Brian P. O’Neill, Comment, Pay Confidentiality: A Remaining Obstacle to Equal Pay After Ledbetter, 40 SETON HALL L. REV. 1217, 1219-20 (2010) (discussing the lack of provisions in the Lilly Ledbetter Fair Pay Act curtailing pay confidentiality policies); Carolyn E. Sorock, Note, Closing the Gap Legislatively: Consequences of the Lilly Ledbetter Fair Pay Act, 85 CHI.-KENT L. REV. 1199, 1211-12 (2010) (noting concerns regarding the statute's override of other established statutes of limitation); Hernaldo J. Baltodano \& David Martinez, Determining the Reach of the Lilly Ledbetter Fair Pay Act, L.A. LAw. 22-24 (June 2010) (identifying contradictions in lower courts in applying the Lilly Ledbetter Fair Pay Act).

92. O’Neill, supra note 91, at 1218-19.

93. Id. at 1221 . 
which statutes of limitation are designed to protect. ${ }^{94}$ The Act's "other practice" language, which allows plaintiffs to bring claims after being "affected" by such practices, contributes to employer uncertainty about what types of practices could trigger a suit. ${ }^{95}$

While several federal pay equity bills have been introduced but not passed since the Lilly Ledbetter Fair Pay Act was enacted-including a reintroduction of the Paycheck Fairness Act in 2013-much of the activity in the pay equity realm has occurred in the states. ${ }^{96}$ State pay equity laws provide additional models for structuring pay equity statutes and, much like their federal counterparts, have had varying degrees of success in closing the pay gap.

\section{B. Survey of State Pay Equity Statutes}

Current state pay equity laws offer varying levels of protection against wage discrimination for employees. Most importantly, state statutes differ in the parity of work responsibilities and duties employees are required to demonstrate before bringing wage discrimination claims and in the geographic scope within which employees can make comparisons to show wage disparities. This section surveys the landscape of current state pay equity laws, provides a deeper analysis of Kansas's statute, and turns to California, Massachusetts, and New York's statutes to develop a framework for proposing changes to Kansas's law in Part III of this Comment.

\section{Four Categories of State Pay Equity Statutes}

States that have pay equity laws on their books can be divided into four categories based on their statutory language. As of January 2017, forty-four states have enacted statutory provisions prohibiting wage discrimination on the basis of sex. ${ }^{97}$ Alabama and Mississippi do not

94. Sorock, supra note 91, at 1211-12.

95. Baltodano \& Martinez, supra note 91, at 22.

96. See Cho \& Kramer, supra note 16, at 4-5 (listing the Equal Employment Opportunity Restoration Act, introduced in both houses of Congress in 2012, the Fair Pay Act, introduced in both houses of Congress in 2013, and the Fair Minimum Wage Act, introduced in both houses of Congress in 2013, as examples of such legislation since the Lilly Ledbetter Fair Pay Act).

97. See Alaska Stat. AnN. § 18.80.220(a)(5) (West 2007); Ariz. Rev. Stat. AnN. § 23-341 (2012) (West); ARK. Code ANN. § 11-4-601 (West 2014); CAL. LAB. CodE $§ 1197.5$ (West 2011); Colo. Rev. Stat. AnN. § 8-5-102 (West 2013); Conn. Gen. Stat. AnN. § 31-75 (West 2011); DeL. CODE AnN. tit. 19, § 1107A (West 2006); Fla. StAT. AnN. § 448.07 (West 2013); GA. CoDE ANN. $\S$ 34-5-3 (West 2003); HAW. REv. STAT. § 378-2.3 (West 2008); IdAHO CODE ANN. § 44-1702 (WEST 2006); 820 ILl. Comp. StAT. ANN. 110/1, 112/1, 125/1 (West 2008); IND. CodE ANN. § 22-2-2-4(d) (West 2005); IOWA CoDE ANN. §§ 70A.18, 216.6A (West 2012); KAN. STAT. ANN. § 44-1205 (West 
have laws requiring employers to equally compensate employees doing equal work regardless of sex. ${ }^{98}$ The District of Columbia, North Carolina, South Carolina, Utah, and Wisconsin do not have specific prohibitions against wage discrimination on the basis of sex; rather, statutes in those jurisdictions have general employment discrimination prohibitions. $^{99}$

Despite the fact that a majority of states have enacted some form of pay equity statutory provisions, statutory language distinguishes those states in four significant ways. ${ }^{100}$ The first two categories paint a broad picture of the context of the pay equity landscape in their respective states. First, some statutes feature provisions specifically tailored to wage discrimination on the basis of sex, while others include sex within a list of characteristics that employers in those states are prohibited from using as the basis for wage discrepancies. ${ }^{101}$ Second, some state statutes

2000); Ky. Rev. Stat. AnN. § 337.420-23 (West 2011); La. ReV. Stat. AnN. §§ 23:301, 23:661 (2014); Me. Rev. Stat. ANN. tit. 26, § 628 (2007); MD. CodE ANN., LAB. \& EMPL. § 3-301 (West 2002); Mass. Gen. Laws ANN. ch. 149, § 105A (West 2013); Мich. CoMP. Laws ANN. $\S \S 408.423$, 750.556 (West 2004); MinN. StAT. ANN. § 181.66 (West 2006); Mo. ReV. STAT. § 290.410 (2000); Mont. Code AnN. § 39-3-104 (2013); Neb. Rev. Stat. AnN. § 48-1221 (West 2009); Nev. Rev. Stat. ANN. § 608.017 (West 2014); N.H. ReV. Stat. ANN. § 275:37 (2010); N.J. STAT. ANN. § 34:11-56.2 (West 2011); N.M. STAT. ANN. § 28-23-1 (West 2013); N.Y. LAB. LAW §§ 194, 198 (McKinney 2009); N.D. Cent. Code AnN. § 34-06.1-01 (West 2008); OHIO ReV. Code ANN. § 4111.17 (West 2016); OKLa. Stat. AnN. tit. 40, 198.1 (West 2014); Or. Rev. Stat. AnN. § 652.220 (West 2011); 43 PA. CONS. STAT. ANN. § 336.1 (West 2009); R.I. GeN. LAWS ANN. § 28-618 (West 2006); S.D. Codified Laws § 60-12-15 (2009); TenN. Code ANN. § 50-2-202 (West 2012); TeX. LAB. CODE ANN. §§ 21.001, 659.001 (West 2015); VT. STAT. ANN. tit. 21, §§ 495(a)(7), 495(b) (West 2007); VA. Code ANN. § 40.1-28.6 (West 2014); WASH. REv. CODE ANN. $\$ 49.12 .175$ (West 2008); W. VA. CoDE ANN. §§ 21-5B-1, 21-5E-1 (West 2002); Wyo. STAT. ANN. § 27-4-301 (West 2007).

98. See also State Equal Pay Laws, NAT'L CONF. OF ST. Legislatures, http://www.ncsl.org/research/labor-and-employment/equal-pay-laws.aspx (last visited Mar. 31, 2017) (listing all states' wage discrimination laws or lack of laws and specifying each statute's language).

99. See D.C. CODE § 2-1402 (2012) (prohibiting general employment discrimination); N.C. Gen. STAT. ANN. § 143-422.1 (West 2000) (prohibiting general employment discrimination); S.C. CODE ANN. § 1-13-30 (2005) (prohibiting general employment discrimination); UTAH CODE ANN. § 34A-5-101 (West 2013) (prohibiting general employment discrimination); WIS. STAT. ANN. § 111.31 (West 2002) (prohibiting general employment discrimination).

100. See State Equal Pay Laws, supra note 98 (showing, based on a survey of statutory text, that four major categories of pay equity laws exist).

101. Compare Alaska Stat. Ann. § 18.80.220(a)(5), Ariz. Rev. Stat. Ann. § 23-340-41, ARK. Code AnN. § 11-4-601, Cal. Lab. Code § 1197.5, Colo. Rev. STAT. AnN. § 8-5-101, ConN. Gen. Stat. AnN. § 31-75, Del. Code AnN. tit. 19, § 1107A, 1113, Fla. Stat. ANN. § 448.07, Ga. Code ANN. § 34-5-3, Haw. Rev. Stat. § 378-2.3, IdAHo Code ANN. § 44-1701, 820 ILl. Comp. Stat. ANN. 110/1, 112/1, 125/1, Ind. CODE ANN. § 22-2-2-4(d), KAN. STAT. ANN. § 44-1205, Ky. Rev. Stat. AnN. § 337.420-23, La. Rev. Stat. AnN. §§ 23:301, 23:661, Me. Rev. Stat. AnN. tit. 26 , § 628, MD. CODE ANN. LAB. \& EMPL. § 3-301, MASS. GEN. LAWS ANN. ch. 149, § 105A, Mich. Comp. Laws ANN. $\S 408.423,750.556$, MinN. Stat. ANN. § 181.66, Mo. Rev. Stat. $§ 290.410$, Mont. Code ANN. § 39-3-104, Neb. Rev. Stat. AnN. § 48-1221, NeV. Rev. Stat. AnN. § 608.017, 
apply to all employers, while others apply only to private or only to public employers.

Statutes in the third and fourth categories incorporate language from enacted and proposed federal legislation. Some state statutes require employees to demonstrate that they received lower wages than other employees on the basis of sex for the "same" or "equal" work, while other statutes require only "comparable" work or include no language governing comparisons of employee responsibilities or skill levels. ${ }^{103}$ More specifically, some state statutes include additional requirements for employees' skill levels, responsibilities, and working conditions that plaintiffs must meet to bring wage disparity claims. ${ }^{104}$

Finally, statutes in the fourth category address the geographic scope plaintiffs are afforded to make wage comparisons. Some state statutes require employees claiming wage discrimination to work at the same establishment, while others allow a broader geographic scope for wage comparison purposes. ${ }^{105}$

N.H. Rev. Stat. AnN. § 275:37, N.J. Stat. AnN. § 34:11-56.2, N.M. Stat. AnN. § 28-23-1, N.Y. LAB. LAW $\S \S 194,198$, N.D. CENT. CODE ANN. § 34-06.1-01, OHIO Rev. Code ANN. § 4111.17, OKLa. Stat. AnN. tit. 40, § 198.1, OR. Rev. Stat. AnN. § 652.220, 43 Pa. Cons. Stat. AnN. $\S$ 336.1, R.I. GEN. LAWS ANN. § 28-6-18, S.D. CODIFIED LAWS § 60-12-15, TENN. CODE ANN. § 50-2202, Tex. Lab. Code AnN. $\S \S 21.001,659.001$, VA. Code ANN. $\S 40.1-28.6$, Wash. Rev. Code ANN. § 49.12.175, W. VA. CODE ANN. §§ 21-5B-1, 21-5E-1, and WYO. STAT. ANN. § 27-4-301, with IOWA CODE ANN. §§ 70A.18, 216.6A, and VT. STAT. ANN. tit. 21, §§ 495(a)(7), 495(b).

102. See, e.g., MinN. StAT. ANN. § 181.66; N.Y. Lab. LaW $\S \S 194,198 ;$ OKLa. STAT. AnN. tit. $40, \S 198.1$ (applying pay equity provisions to private employers only); LA. REV. STAT. ANN.

$\S \S 23: 301,23: 661$; TEX. LAB. CODE ANN. $\S \S 21.001,659.001$ (applying pay equity provisions to public employers only); FLA. STAT. ANN. § 448.07; GA. CODE ANN. § 34-5-3; 820 ILL. COMP. STAT. ANN. 110/1, 112/1, 125/1; IND. CODE ANN. § 22-2-2-4(d); Ky. REV. STAT. ANN. § 337.420-23; Mich. COMP. LAWS ANN. $\S ~ 408.423,750.556$; N.M. STAT. ANN. $§ 28-23-1$ (applying pay equity provisions to employers that hire a certain minimum number of employees).

103. Compare Alaska Stat. AnN. § 18.80.220(a)(5), ARiz. Rev. Stat. AnN. § 23-340-41, Del. Code AnN. tit. 19, § 1107A, 1113, Fla. Stat. AnN. § 448.07, Ga. Code AnN. § 34-5-3, HaW. Rev. Stat. § 378-2.3-2.5, InD. CODE ANN. § 22-2-2-4(d), Kan. STAT. AnN. § 44-1205, MinN. STAT. ANN. § 181.66, Mo. ReV. STAT. § 290.410, Mont. Code ANN. § 39-3-104, Neb. ReV. Stat. ANN. § 48-1221, Nev. Rev. Stat. AnN. §608.017, N.H. Rev. Stat. AnN. § 275:37, N.M. Stat. AnN. § 2823-1, N.Y. LAB. LAW §§ 194, 198, OHIO REV. CODE ANN. § 4111.17, R.I. GEN. LAWS ANN. § 28-618, VA. CODE ANN. § 40.1-28.6, W. VA. CODE ANN., §§ 21-5B-1, 21-5E-1, and Wyo. STAT. AnN. § 27-4-301, with ARK. Code ANN. § 11-4-601, CAL. LAB. CODE § 1197.5, COLO. ReV. STAT. ANN. § 85-101, Conn. Gen. STAT. ANN. § 31-75, IDAHO CODE ANN. § 44-1701, 820 ILl. CoMP. STAT. ANN. 110/1, 112/1, 125/1, Ky. REV. STAT. ANN. § 337.420-23, LA. REV. STAT. ANN. §§ 23:301, 23:661, Me. Rev. Stat. Ann. tit. 26, § 628, Md. Code Ann., Lab. \& Empl. § 3-301, Mass. Gen. Laws ANN. ch. 149, § 105A, Mich. COMP. LAWS ANN. $\S \S 408.423,750.556$, N.J. STAT. ANN. $\$ 34: 11-56.2$, N.D. Cent. Code AnN. § 34-06.1-01, OKLa. Stat. AnN. tit. 40, § 198.1, OR. Rev. Stat. AnN. §

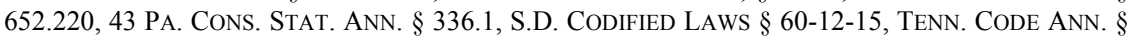
50-2-202, TeX. LAB. CODE ANN. $\S \S 21.001,659.001$, and WASH. REV. CODE ANN. $\$ 49.12 .175$.

104. Del. Code ANN. tit. 19, § 1107(A), 1113; Fla. Stat. ANN. § 448.07; Ga. Code ANN. § 345-3; Haw. Rev. Stat. § 378-2.3; 820 ILl. Comp. StAT. ANN. 110/1, 112/1, 125/1; IND. CodE ANN. $\S 22-2-2-4(d) ;$ MinN. STAT. ANN. § 181.66; N.Y. LAB. LAW $\S ~ 194,198$.

105. See Ariz. Rev. Stat. AnN. § 23-340-41; Del. Code AnN. tit. 19, § 1107(A), 1113; GA. 


\section{(a) Specificity of Wage Discrimination Provisions}

Broadly, forty-two of the forty-four states that have enacted pay equity laws, including Kansas, have done so by specifically prohibiting wage discrimination on the basis of sex. ${ }^{106}$ However, Iowa and Vermont have included sex as one of several categories upon which employers cannot base wage discrepancies, analogous to Title VII's provisions. ${ }^{107}$ Iowa's wage discrimination statute broadly prohibits discrimination based on the "age, race, creed, color, sex, sexual orientation, gender identity, national origin, religion, or disability" of an employee. ${ }^{108}$ Vermont's statute also includes sex as one prohibited basis for wage differences within the state's employment discrimination law. ${ }^{109}$

\section{(b) Applicability of State Statutes to Employers}

Thirteen states place some form of restriction on the applicability of their pay equity statutes, whether those statutes apply only to private or public employers or whether the statutes require an employer to have a minimum number of employees before the law applies. ${ }^{110}$ While

Code AnN. § 34-5-3; Haw. Rev. Stat. § 378-2.3-2.5; IDAho Code AnN. § 44-1701; Ind. Code AnN. §22-2-2-4(d); IOWA Code ANN. §§ 70A.18, 216.6A; KAN. STAT. ANN. § 44-1205; Ky. ReV. Stat. Ann. § 337.420-23; Me. Rev. Stat. Ann. tit. 26, § 628; Мich. Comp. Laws AnN. §§ 408.423, 750.556; Mo. Rev. Stat. § 290.410; Mont. Code AnN. § 39-3-104; Neb. Rev. Stat. AnN. $\S 48-1221$; NeV. Rev. Stat. AnN. § 608.017; N.M. Stat. ANN. § 28-23-1; N.Y. Lab. LaW §§ 194, 198; 43 PA. CONS. STAT. ANN. § 336.1; TENN. CODE ANN. § 50-2-202; VA. CODE ANN. § 40.1-28.6; WYO. STAT. ANN. § 27-4-301 (requiring plaintiffs bringing wage discrimination claims to work at the "same establishment" as the employee or employees to whom plaintiffs compare their wages); see also ALASKA STAT. ANN. $\S 18.80 .220$ (a)(5) (requiring that plaintiffs compare their wages to other employees' wages within the "same locality").

106. See Alaska Stat. AnN. § 18.80.220(a)(5); ARiz. Rev. Stat. AnN. § 23-340, 341; ARK. Code AnN. § 11-4-601; CAL. Lab. Code § 1197.5; Colo. Rev. Stat. AnN. § 8-5-101; ConN. Gen. Stat. ANN. § 31-75; 19 Del. Code ANN. tit. 19, § 1107(a), 1113; Fla. Stat. ANN. § 448.07; GA. Code AnN. § 34-5-3; Haw. Rev. Stat. § 378-2.3-2.5; IdAho Code AnN. § 44-1701; 820 Ill. COMP. STAT. ANN. 110/1, 112/1, 125/1; IND. CODE ANN. \$22-2-2-4(d); KAN. STAT. ANN. § 44-1205; Ky. Rev. Stat. AnN. § 337.420-23; La. Rev. Stat. AnN. §§ 23:661, 23:301; ME. Rev. Stat. AnN. tit. 26, § 628; MD. CODE ANN., LAB. \& EMPL. § 3-301; MASS. GEN. LAWS ch. 149, § 105A; Mich. Comp. Laws ANN. $\S \S 750.556,408.423$; MinN. STAT. ANN. $\S 181.66$; Mo. ANN. STAT. $\S 290.410$; Mont. Code AnN. § 39-3-104; NEB. ReV. Stat. AnN. § 48-1221; NeV. Rev. STAT. ANN. § 608.017; N.H. Rev. Stat. ANN. § 275:37; N.J. Stat. AnN. § 34:11-56.1; N.M. STAt. ANN. § 28-23-1; N.Y. LaB. LaW §§ 194, 198; N.D. CENT. CODE ANN. § 34-06.1-01; OHIO REv. CODE ANN. § 4111.17; OKLa. Stat. AnN. tit. 40, $§ 198.1$; OR. Rev. Stat. AnN. $~ 652.220 ; 43$ Pa. Cons. Stat. AnN. $\S$ 336.1; R.I. GEN. LAWS ANN. § 28-6-18; S.D. CODIFIED LAWS § 60-12-15; TENN. CODE ANN. § 50-2201; TEX. LAB. CODE ANN. $\S$ 659.001, 21.001; VA. CODE ANN. § 40.1-28.6; WASH. REv. CodE ANN. § 49.12.175; W. VA. CODE ANN. §§ 21-5B-1, 21-5E-1; Wyo. STAT. ANN. § 27-4-301.

107. See Iowa Code AnN. $\S \S 70 A .18,216.6$ A; VT. StAT. AnN. tit. 21, $\S$ 495(a)(7), 495(b).

108. IOWA CODE ANN. $\S \S 70 A .18,216.6 \mathrm{~A}$.

109. VT. STAT. ANN. tit. 21, §§ 495(a)(7), 495(b).

110. See State Equal Pay Laws, supra note 98. 
Kansas's statute makes no such distinctions, ${ }^{111}$ Minnesota, New York, and Oklahoma's statutes all solely apply to private employers, ${ }^{112}$ and Louisiana and Texas's statutes apply only to public employers. ${ }^{113}$ Several states require an employer, regardless of whether private or public, to have a certain number of employees to be subject to the statute. ${ }^{114}$ For example, Nebraska's statute only applies to private employers if an employer has fifteen or more employees. ${ }^{115}$

\section{(c) Equal, Comparable, and Similar Work Requirements}

Substantively, states fall along a wider spectrum with respect to their requirements that employees bringing wage discrimination claims do "equal work" or only "comparable work" to their higher-paid counterparts. ${ }^{116}$ Twenty-two of the forty-three states that have enacted pay equity laws, including Kansas, statutorily require that employees receiving different wages do "equal" or the "same" work. ${ }^{117}$ This

111. KAN. StAT. ANN. §44-1205 (West 2000).

112. MinN. STAT. ANN. § 181.66 (West 2006); N.Y. LAB. LAW $\S \S 194,198$ (McKinney 2009); OKLA. STAT. ANN. tit. 40, 198.1 (West 2014).

113. LA. REv. STAT. ANN. §§ 23:301, 23:661 (2014); TeX. LAB. CODE ANN. §§ 21.001, 659.001 (West 2015).

114. Fla. Stat. AnN. § 448.07 (West 2013); Ga. Code AnN. § 34-5-3 (West 2003); 820 Ill. COMP. Stat. ANN. 110/1, 112/1, 125/1 (West 2008); IND. CODE ANN. § 22-2-2-4(d) (West 2005); Ky. ReV. Stat. AnN. § 337.420-23 (West 2011); Mich. Comp. LaWs AnN. §§ 408.423, 750.556 (West 2004); N.M. STAT. ANN. § 28-23-1 (West 2013).

115. Neb. ReV. Stat. AnN. § 48-1221 (West 2009).

116. See Alaska Stat. AnN. § 18.80.220(A)(5) (West 2007); ARIZ. Rev. Stat. ANN. § 23-34041 (2012) (West); ARK. CODE ANN. § 11-4-601 (West 2014); CAL. LAB. CODE $§ 1197.5$ (West 2011); Colo. Rev. Stat. AnN. § 8-5-101 (West 2013); Conn. Gen. Stat. AnN. § 31-75 (West 2011); Del. Code ANN. tit. 19, § 1107A, 1113 (West 2006); Fla. STAT. ANN. $\S 448.07$ (West 2013); Ga. CodE ANN. § 34-5-3 (West 2003); HAW. ReV. STAT. § 378-2.3 (West 2008); IDAHo CodE ANN. § 44-1701 (West 2006); 820 Ill. COMP. STAT. ANN. 110/1, 112/1, 125/1 (West 2008); IND. CODE ANN. § 22-22-4(d) (West 2005); KAN. Stat. AnN. § 44-1205 (West 2000); Ky. ReV. STAT. ANN. § 337.420-23 (West 2011); LA. Rev. Stat. ANN. §§ 23:301, 23:661 (2014); ME. Rev. Stat. ANN. tit. 26, § 628 (2007); MD. CODE ANN., LAB. \& EMPL.§ 3-301 (West 2002); MASS. GEN. LAWS ANN. ch. 149, § 105A (West 2013); Mich. COMP. LAWS ANN. §§ 408.423, 750.556 (West 2004); MinN. STAT. ANN. § 181.66 (West 2006); Mo. Rev. STAT. § 290.410 (2000); MonT. CODE ANN. § 39-3-104 (2013); NeB. ReV. STAT. ANN. § 48-1221 (West 2009); NeV. REV. Stat. ANN. § 608.017 (West 2014); N.H. ReV. STAT. ANN. § 275:37 (2010); N.J. STAT. ANN. § 34:11-56.1 (West 2011); N.M. STAT. ANN. § 28-23-1 (West 2013); N.Y. LAB. LAW §§ 194, 198 (McKinney 2009); N.D. CENT. CODE ANN. § 34-06.1-01 (West 2008); Ohio Rev. Code AnN. § 4111.17 (West 2016); OKLa. Stat. AnN. tit. 40, § 198.1 (West 2014); OR. ReV. STAT. ANN. § 652.220 (West 2011); 43 PA. CONS. STAT. ANN. § 336.1 (West 2009); R.I. GEN. LAWS ANN. § 28-6-18 (West 2006); S.D. CODIFIED LAWS § 60-12-15 (2009); TENN. CODE ANN. § 50-2-202 (West 2012); TEX. LAB. CODE ANN. §§ 21.001, 659.001 (West 2015); VA. CODE ANN. § 40.1-28.6 (West 2014); Wash. ReV. Code ANN. § 49.12.175 (West 2008); W. VA. CODE, ANN. §§ 21-5B-1, 21-5E-1 (West 2002); Wyo. STAT. ANN. § 27-4-301 (West 2007).

117. Alaska Stat. AnN. $\$ 18.80 .220$ (a)(5) (West 2007); ARIZ. Rev. STAt. ANN. § 23-340-341 (West 2012); Del. Code ANN. tit. 19, §§ 1107(a), 1113 (West 2006); Fla. STAT. ANN. $\$ 448.07$ (West 2013); GA. CODE ANN. § 34-5-3 (West 2003); HAW. REV. STAT. § 378-2.3 (West 2008); IND. 
standard mirrors the Equal Pay Act's "equal work" language. ${ }^{118}$ As under the federal statute, the definition of equal work allows courts to take into consideration the skill, effort, responsibility, and conditions under which employees work to determine if the jobs are in fact equal. ${ }^{119}$

The remaining twenty-one states allow more flexibility by requiring "comparable work." 120 The trend toward incorporating the comparable work standard began in the 1970s, and the discussion became national in the 1980s. ${ }^{121}$ Comparable work systems "seek to give individuals working on jobs involving similar skills, training, work conditions, or other terms of employment, the same wages." ${ }^{122}$ Such systems can be executed by assigning points to the aforementioned factors which, when totaled, provide "an aggregate of ... a job's "worth"” and theoretically would result in equal compensation. ${ }^{123}$ However, comparable work standards are complicated by the discretion that employers, government agencies, and judges have in evaluating the criteria used to establish comparable employment positions. ${ }^{124}$

Some states create additional guidelines for comparing jobs and wages. For example, some states include language in their pay equity laws requiring equal work but only "similar" working conditions. ${ }^{125}$ Delaware, Florida, Georgia, Hawaii, Illinois, Indiana, Minnesota, and

Code AnN. § 22-2-2-4(d) (West 2005); KAn. StAT. AnN. § 44-1205 (West 2000); MinN. STAT. AnN. $\S 181.66$ (West 2006); Mo. Rev. STAT. § 290.410 (2000); Mont. Code AnN. § 39-3-104 (2013); Neb. Rev. Stat. ANN. § 48-1221 (West 2009); NEV. ReV. STAt. ANN. § 608.017 (West 2014); N.H. REV. STAT. ANN. § 275:37 (2010); N.M. STAT. ANN. § 28-23-1 (West 2013); N.Y. LAB. LAW §§ 194, 198 (McKinney 2009); OHIO REV. CODE ANN. \$ 4111.17 (West 2016); R.I. GEN. LAWS ANN. § 28-618 (West 2006); VA. Code ANN. § 40.1-28.6 (West 2014); W. VA. CODE. ANN. §§ 21-5B-1, 21-5E-1 (West 2002); WYO. STAT. ANN. §27-4-301 (West 2007).

118. 29 U.S.C. $\$ 206(d)(1)(2012)$.

119. Wyman, supra note 22 , at 37-39.

120. ARK. Code AnN. § 11-4-601; CAl. Lab. Code § 1197.5; Colo. Rev. Stat. AnN. § 8-51021; ConN. Gen. Stat. ANN. § 31-75; IdAho Code AnN. § 44-1701; 820 ILl. Comp. STAT. ANN. 110/1, 112/1, 125/1; KY. REV. STAT. ANN. § 337.420-23; LA. REV. STAT. ANN. §§ 23:301, 23:661; Me. Rev. Stat. AnN. tit. 26, § 628; Md. Code AnN., LAB. \& EMPL. § 3-301; Mass. Gen. LawS ANN. ch. 149, § 105A; MiCH. COMP. LAwS ANN. §§ 408.423, 750.556; N.J. STAT. ANN. § 34:11-56.1; N.D. Cent. Code ANN. § 34-06.1-01; OKLa. Stat. AnN. tit. 40, § 198.1; OR. Rev. Stat. AnN. §

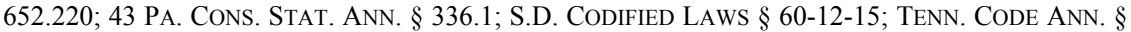
50-2-201; TEX. LAB. CODE ANN. §§ 21.001, 659.001; WASH. REV. CODE ANN. § 49.12.175.

121. Daniel N. Kuperstein, Note, Finding Worth in the New Workplace: The Implications of Comparable Worth's Reemergence in the Global Economy, 24 HoFSTRA LAB. \& EMP. L.J. 363, 378-79 (2007).

122. Id. at 376 .

123. Id.

124. Id. at 377 .

125. Del. Code AnN. tit. 19, § 1107A, 1113 (West 2006); Fla. Stat. AnN. § 448.07 (West 2013); Ga. Code ANN. § 34-5-3 (West 2003); HAW. ReV. STAT. § 378-2.3 (West 2008); 820 ILL. COMP. STAT. ANN. 110/1, 112/1, 125/1 (West 2008); IND. CODE ANN. § 22-2-2-4(d) (West 2005); MinN. STAT. ANN. § 181.66 (West 2006); N.Y. LAB. LAW §§ 194, 198 (McKinney 2009). 
New York all mandate that jobs being compared require "equal skill, effort and responsibility" and are "performed under similar working conditions." 126

\section{(d) Geographic Scope of Comparison}

Still other states create restrictions on the geographic scope within which employees can compare wages to other employees' compensation to demonstrate wage discrimination. These "establishment" provisions are analogous to the Equal Pay Act's establishment language, which the Paycheck Fairness Act attempted to remove. ${ }^{127}$ Alaska's statute, for example, requires only that employee comparisons occur within the "same locality."128 However, Kansas, among twenty-one other states, requires employees bringing wage discrimination claims to compare their wages to higher-paid employees at the same "establishment." 129

\section{Kansas's Current Pay Equity Statute}

Despite its lack of flexibility when compared to California, New York, and Massachusetts's statutory provisions, which will be discussed in the next section, Kansas's pay equity law does share statutory language with other states. With respect to the four divisions differentiating state pay equity statutes nationally, ${ }^{130}$ Kansas's current pay equity statute, codified at Kan. Stat. Ann. $\S \S 44-1205$, 44-1210, and 44-1211, applies to all employers, public and private. ${ }^{131}$ The law falls into the "equal work" category with twenty-one other states. ${ }^{132}$ Kansas's statute does not include language that would substantially broaden the scope of comparison employees bringing claims under the statute could

\footnotetext{
126. Id

127. 29 U.S.C. § 206(d)(1) (2012); S. 841, 109th Cong. § 3(c)(1)-(2) (2005).

128. Alaska Stat. AnN. $\S 18.80 .220$ (a)(5) (West 2007).

129. Kan. Stat. AnN. § 44-1205 (West 2000). See also Ariz. Rev. Stat. Ann. § 23-340-41 (West 2012); Del. Code ANN. tit. 19, § 1107A, 1113 (West 2006); GA. COdE ANN. § 34-5-3 (West 2003); HAW. Rev. STAT. § 378-2.3 (West 2008); IDAHO CODE ANN. § 44-1701 (West 2006); IND. CODE ANN. § 22-2-2-4(d) (West 2005); IOWA CODE ANN. §§ 70A.18, 216.6A (West 2012); Ky. ReV. Stat. ANN. § 337.420-23 (West 2011); Me. Rev. Stat. ANN. tit. 26, § 628 (2007); Мich. Comp. Laws ANN. §§ 408.423, 750.556 (West 2004); Mo. ReV. STAT. § 290.410 (2000); Mont. Code ANN. § 39-3-104 (2013); NeB. ReV. STAt. ANN. § 48-1221 (West 2009); Nev. ReV. STAT. ANN. § 608.017 (West 2014); N.M. STAT. ANN. § 28-23-1 (West 2013); N.Y. LAB. LAW §§ 194, 198 (McKinney 2009); 43 Pa. Cons. Stat. ANN. § 336.1 (West 2009); TenN. Code AnN. § 50-2-202 (West 2012); VA. CODE ANN. § 40.1-28.6 (West 2014); Wyo. STAT. ANN. § 27-4-301 (West 2007).

130. See supra Part II.B.1.

131. Kan. STAT. ANN. §§ 44-1205, 44-1210, 44-1211 (West 2000).

132. Id. § 44-1205.
} 
use for support. For example, the state only allows for comparison of "similar working conditions"- the statute requires equality of the employee "skill, effort, and responsibility" being evaluated. ${ }^{133}$ Kansas's statute also does not have wage transparency protections, as the federal Paycheck Fairness Act would have instituted, for employees who discuss compensation. ${ }^{134}$ The law does, however, include the same affirmative defenses as the Equal Pay Act and Title VII: seniority, merit systems, quantity or quality of production, or factors other than sex. ${ }^{135}$

Provisions governing damages for wage discrimination in Kansas mirror other states' statutes but add monetary penalties for certain conduct. ${ }^{136}$ Kansas's law requires employers in violation of the statute to pay employees the total amount of unpaid wages and overtime compensation, notwithstanding any agreement between the employer and employee. ${ }^{137}$ The statute allows for a minimum $\$ 250$ and maximum $\$ 1,000$ fine for violations of its pay equity provision. ${ }^{138}$ Kansas's law does include an anti-retaliation provision: employers that fire or broadly discriminate against employees because of complaints filed, legal claims filed, or testimony given in a wage discrimination case under the statute are automatically considered to have violated the statute and garner an additional fine of $\$ 250$ to $\$ 1,000 .{ }^{139}$ However, Kansas's statute does not include liquidated damages tied to the total amount of underpaid wages. ${ }^{140}$

3. The New Frontier of Pay Equity: California, New York, and Massachusetts's Statutes

Certain state legislatures' trends toward augmenting pay equity statutes have been deemed "sweeping changes" compared to the relative stagnancy of federal pay equity statutes. ${ }^{141}$ New York and California enacted pay equity statutes at the end of 2015 that went into effect at the beginning of 2016 and 2017, respectively. ${ }^{142}$ A session law enacted in Massachusetts in 2016 expands that state's pay equity provisions in

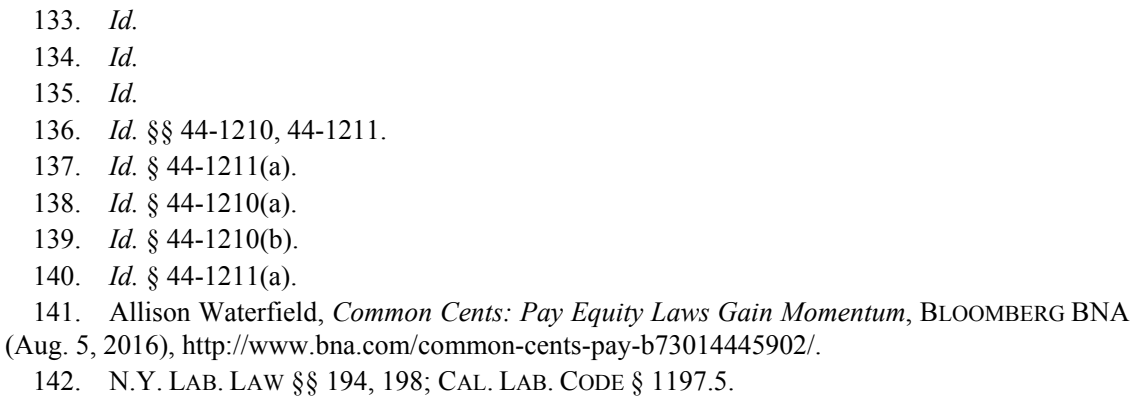


"impactful" and "noteworthy" ways in comparison to other states' laws. ${ }^{143}$ These laws demonstrate shifts away from the "equal pay for equal work" standard espoused by the Equal Pay Act and include amendments that more narrowly tailor affirmative defenses, include new anti-retaliation provisions, and incorporate additional damages.

\section{(a) California's 2015 Pay Equity Amendments}

California's new pay equity provisions broadened employees' abilities to bring wage discrimination claims and strengthened damages and non-retaliation provisions. The law moved the state from an "equal pay for equal work" standard to a "substantially similar work" standard, amended affirmative defenses and damages, and added language preventing employers from retaliating against employees bringing wage discrimination claims. ${ }^{144}$ The state's new statute marks a shift away from Equal Pay Act-like language toward provisions more reminiscent of those proposed in the failed Paycheck Fairness Act. ${ }^{145}$ The amended provisions require employees filing wage discrimination claims to show that they and their counterparts of the opposite sex perform "substantially similar work, when viewed as a composite of skill, effort, and responsibility ... under similar working conditions . . .."146

California's statute also limits employer defenses and adds damages available to plaintiffs and anti-retaliation provisions. Systems based on seniority, merit, measures of earnings based on production quantity or quality, or "a bona fide factor other than sex" (such as "education, training, or experience") are legal bases under the California law upon which to differentiate among employee wages. ${ }^{147}$ But the law defines a "factor other than sex" more specifically than its predecessor: such a factor cannot be "based on or derived from" employees' sexes, must be related to the employees' jobs, and must be "consistent with a business necessity." A business necessity is an "overriding legitimate business purpose" that the factor fulfills. ${ }^{149}$ The law negates such affirmative defenses, however, if an employee can show an "alternative business practice... that would serve the same business purpose without

\footnotetext{
143. Waterfield, supra note 141.

144. CAL. Lab. CODE $\S 1197.5$ (a).

145. See supra Part II.A.1.

146. CAL. LAB. CODE $§ 1197.5(a)$.

147. Id. $\S 1197.5(\mathrm{a})(1)(\mathrm{A})-(\mathrm{D})$.

148. Id. $\S 1197.5(\mathrm{a})(1)(\mathrm{D})$.

149. Id.
} 
producing the wage differential."150 To be non-pretextual, these factors - or affirmative defenses - must be "applied reasonably" and serve as the reasoning behind the wage difference in its entirety. ${ }^{151}$ Affirmative defenses under California's statute are substantially more defined and place a higher burden on employers than the federal pay equity statutes do. ${ }^{152}$ Also more strictly defined in the new statute are damages, which have changed to match the federal Equal Pay Act's (and Paycheck Fairness Act's) damages ${ }^{153}$ : in addition to unpaid wages with interest, the state statute also allows for the same amount in liquidated damages. ${ }^{154}$

Finally, the California statute includes new provisions governing the relationship between employers and employees. Similar to Kansas's statute, the law has an anti-retaliation provision that applies to employers with respect to employees who make pay equity claims. ${ }^{155}$ Unlike Kansas's law, however, the California statute also restricts employers from creating rules that prohibit employees from talking about their wages - though employees cannot be forced to discuss their wages - or prohibit "encouraging any other employee to exercise his or her rights" under the law. ${ }^{156}$ This amendment also moves California's new statute toward the provisions envisioned by the Paycheck Fairness Act. ${ }^{157}$

\section{(b) New York's 2015 Pay Equity Amendments}

New York's pay equity law closely resembles the new provisions in California's law with a few key differences in the scope of comparison employees can make when bringing claims and available affirmative defenses. New York's statute is more restrictive than California's law in the breadth employees have to compare themselves to their counterparts to prove wage discrepancies: the law requires employees to perform jobs that necessitate "equal skill, effort and responsibility... under similar working conditions ...."158 The four acceptable factors employers can use as bases for wage differences are the same as those in California's law: seniority, merit, measures of earnings based on production quantity

\footnotetext{
150. Id. See Waterfield, supra note 141.

151. CAL. LAB. CODE $§ 1197.5(\mathrm{a})(2)-(3)$.

152. See supra Part II.A.

153. See supra Part II.A.1.

154. CAL. LAB. CODE $§ 1197.5(\mathrm{c})$.

155. Id. $\S 1197.5(\mathrm{k})(1)$.

156. Id.

157. See supra Part II.A.2.

158. N.Y. LAB. LAW § 194(1) (McKinney 2009).
} 
or quality, or "a bona fide factor other than sex." ${ }^{\prime 59}$ New York's statute requires that when employers use "factor[s] other than sex" to explain wage discrepancies, those factors cannot cause a "disparate impact on the basis of sex." ${ }^{\text {"160 }}$ California's statute does not include such a mandate'. ${ }^{161}$ Such a factor, as in California's statutory language, must be "consistent with business necessity." 162 In New York's statute, a "business necessity" is a factor that "bears a manifest relationship to the employment in question."163 Further, the statute negates these affirmative defenses if an employee shows not only "an alternative employment practice exists that would serve the same business purpose and not produce [a wage] differential," but also "that the employer has refused to adopt such alternative practice."164 New York's statute therefore places a second burden on plaintiffs that California's statute does not. ${ }^{165}$

Another difference in New York's law is its requirement that employees work at the "same establishment" to form a basis of comparison under the state's pay equity statute, which California does not mandate. ${ }^{166}$ However, further statutory definition demonstrates that this requirement is broader than it appears on its face and broader than the Equal Pay Act's "same establishment" provision. ${ }^{167}$ New York's law allows for employees filing wage disparity claims to compare themselves to other employees working "for the same employer at workplaces located in the same geographical region, no larger than a county, taking into account population distribution, economic activity, and/or the presence of municipalities." 168 For instance, assuming a court found a favorable population distribution and sufficient municipalities and economic activity in Onondaga County, New York, where the city of Syracuse is located, an employee would be able to compare his or her wages to another employee of the same employer anywhere in Onondaga County.

Finally, New York's law also prohibits employers from restricting employees' conversations about wages, a provision absent from Kansas's

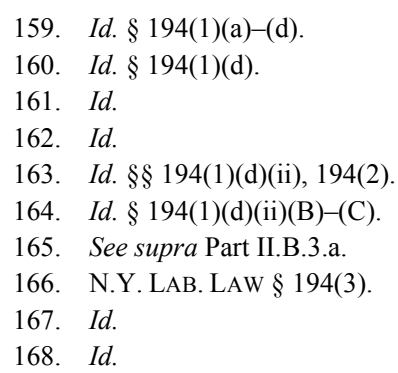


statute. ${ }^{169}$ However, New York's law allows for some limitations on wage discussions, which California's statute does not incorporate. ${ }^{170}$ In New York, employers can "establish reasonable workplace and workday limitations on the time, place and manner for inquires [sic] about, discussion of, or the disclosure of wages." ${ }^{171}$ An example might include a prohibition against two employees discussing a third employee's wages without that employee's consent. ${ }^{172}$ New York's statute allows an employer to use an employee's violation of such a reasonable limitation on wage discussions as an affirmative defense. ${ }^{173}$ Consistent with California's pay equity statute, however, New York's law does not obligate an employee to reveal or discuss his or her wages. ${ }^{174}$

A separate section of New York's statute addresses damages. ${ }^{175}$ Employees can recover the total amount of underpaid wages and, as in California's statute, up to the same amount in liquidated damages. ${ }^{176}$ Courts award liquidated damages if an employer cannot show "a good faith basis to believe that its underpayment of wages was in compliance with the law." 177 However, in contrast to California's statute, employees bringing claims in New York can recover up to three times the amount of underpaid wages if they prove their employers' violation of the statute was willful. ${ }^{178}$

(c) Massachusetts's 2016 Pay Equity Amendments

Massachusetts's recently passed pay equity session law also bears similarities to California and New York's statutes, though Massachusetts's law broadens the recovery available to employees bringing claims. ${ }^{179}$ Massachusetts has imported the "comparable work" standard that several other states use. ${ }^{180}$ The state's new statute requires employees claiming wage discrimination to show they do "comparable work" to employees used as a basis for comparison. ${ }^{181}$ The law defines

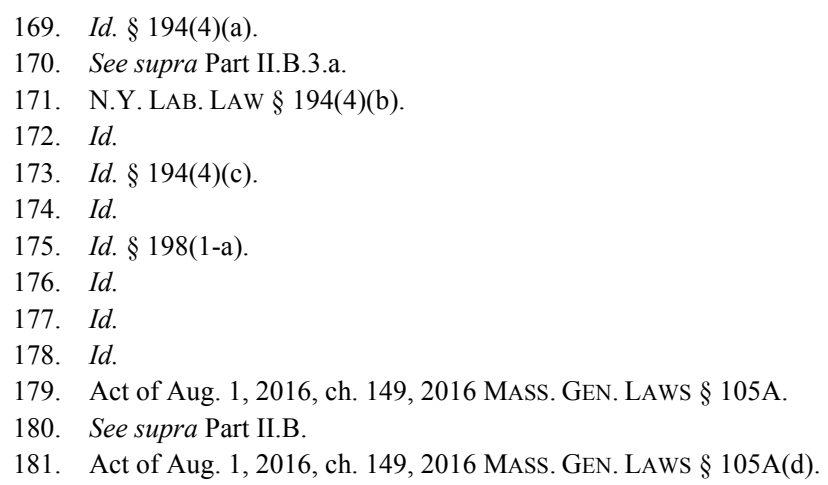


comparable work as that which "requires substantially similar skill, effort and responsibility and is performed under similar working conditions"language that mirrors California's statutory text. ${ }^{182}$ Massachusetts's statute, however, also adds that "a job title or ... description alone" is not determinative of comparable jobs. ${ }^{183}$ Massachusetts also more closely defines "working conditions"-unlike California and New York - as a combination of "reasonable shift differentials" and "the physical surroundings and hazards encountered by employees performing a job," among other factors. ${ }^{184}$

Massachusetts's statute includes variations of the affirmative defenses that California and New York's statutes incorporate. These include systems based on seniority or merit or that "measures earnings by quantity or quality of production, sales, or revenue," as well as differences in "education, training or experience to the extent such factors are reasonably related to the particular job in question." 185 However, Massachusetts's law also includes the employer's location and the "regular[ity] and necess[ity]" of employee travel as additional employer justifications for pay differentials. ${ }^{186}$

Massachusetts's law incorporates anti-retaliation provisions similar to those in California and New York's statutes, though Massachusetts's statute more specifically defines permissible conversations about wages and protections from retaliation. The law restricts employers' ability to curtail employee discussions about wages. ${ }^{187}$ However, Massachusetts's statute also prohibits questions about past wages a prospective employee earned or criteria for past wages unless the prospective employee consents to disclose such information. ${ }^{188}$ The anti-retaliation provision, similar to the analogous provision in Kansas's law, protects employees filing complaints, voicing opposition to practices that would be violations of the statute, testifying about investigations under the statute, or discussing or asking about their own or other employees' wages. ${ }^{189}$

Damages under Massachusetts's law are the same as those under California and New York's laws: the total amount of unpaid wages and up to the same amount in liquidated damages. ${ }^{190}$ The statute adds that

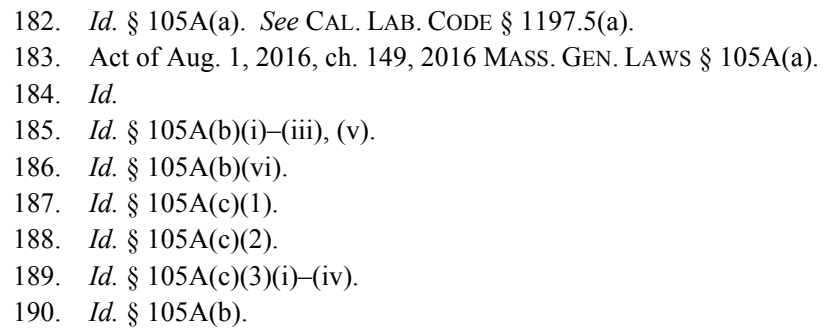


"agreement[s] between the employer and ... employee to work for less than the wage to which the employee is entitled" under the statute and the employee's "previous wage or salary history" are not available as affirmative defenses. ${ }^{191}$

\section{ANALYSIS}

Despite both the federal government and most states' enactments of laws prohibiting wage disparities based on sex, the wage gap persists. ${ }^{192}$ Kansas in particular runs the risk of falling well behind the movement toward expanding pay equity statutes. The state did not shift from its "equal pay for equal work" framework to a "comparable work" standard when the latter was introduced in the 1970s and 1980s. ${ }^{193}$ The "equal work" standard presents a significant hurdle for plaintiffs: rates of success under older pay equity regimes such as the Equal Pay Act, which included an "equal work" provision, are as low as $24 \%$ in federal appellate courts, ${ }^{194}$ with widely fluctuating rates across the federal circuits. ${ }^{195}$ As states begin to broaden their pay equity laws beyond even the "comparable work" standard, Kansas likely will fall further out of sync with national pay equity trends if it does not make a statutory change.

To take more effective steps to close its persistent wage gap, Kansas should adopt common portions of the California, Massachusetts, and New York laws as well as portions of Paycheck Fairness Act and Lilly Ledbetter Fair Pay Act to more adequately enable plaintiffs to bring pay equity claims and address the aforementioned economic policy concerns. Kansas should shift from an "equal work" standard to a "comparable work" or "substantially similar work" standard. This would allow plaintiffs to avoid the strict interpretations of "equal work" language, as employees bringing claims under the Equal Pay Act have experienced. The state should also adopt provisions that provide better definitions of the affirmative defenses available to employers to curtail the

\footnotetext{
191. Id.

192. Wyman, supra note 22, at 24-25; Bureau of Labor Statistics, Women's Earnings 83 Percent of Men's, But Vary by Occupation, U.S. DEP'T OF LAB. (Jan. 15, 2016), http://www.bls.gov/opub/ted/2016/womens-earnings-83-percent-of-mens-but-vary-byoccupation.htm.

193. See supra Part II.B.1.

194. Keiko Lynn Yoshino, Note, Reevaluating the Equal Pay Act for the Modern Professional Woman, 47 VAL. U. L. REV. 585, $611 \mathrm{n} .150$ (2013) (noting that plaintiffs bringing claims under the Equal Pay Act in the United States Court of Appeals for the Seventh Circuit have a 24\% success rate and that plaintiffs in the Eighth Circuit have a $39 \%$ percent success rate, but also that plaintiffs in the Sixth Circuit and D.C. Circuit have success rates of $85 \%$ and $75 \%$, respectively).

195. Id
} 
development of pretextual reasons for wage disparities under "equal work" statutory regimes. ${ }^{196}$ Finally, Kansas should amend its pay equity statute to include protections for wage discussions to provide employees with more opportunities for notice about potential wage disparities. ${ }^{197}$

The rationale behind the statutory models Kansas should follow in California, Massachusetts, and New York is certainly grounded in the basic social justice proposition that women should earn the same wages as men do for performing the same or substantially similar work. ${ }^{198}$ This reasoning is saliently and importantly evident in the language these three state legislatures have used in their bills to strengthen pay equity laws. ${ }^{199}$ These three laws, however, were also driven in large part by the economic burden lower wages are placing on women, families, and those states' economies as a whole. ${ }^{200}$ Because women are working in higher numbers than ever before, the economic concerns that California, Massachusetts, and New York's legislatures expressed are important factors supporting broader pay equity laws in states such as Kansas, which has also seen women become an integral part of its workforce.

\section{A. The Economic Argument for Pay Equity}

The wage gap between men and women has closed only slightly despite years of Congress and state legislatures' statutory enactments aimed at combating this disparity. While women's employment decisions drive some of these wage discrepancies, data show that lawmakers and courts alike should not extrapolate this explanation to assume women have independently created the persistent national wage

196. See supra Part II.A.1.

197. See Bridget Sasson, Comment, The Equal Pay Act: Almost Fifty Years Later, Why Wage Gap Still Exists, 15 DuQ. BuS. L.J. 73, 83-84 (2012) (citing the Supreme Court's Ledbetter decision and Justice Ginsburg's dissent and noting that without wage transparency, employees have little ability to know whether a wage gap exists).

198. See S.B. 358, 2015 Leg., Reg. Sess. (Cal. 2015); A06075, 201st Leg., Reg. Sess. (N.Y. 2015) (California noted in its bill text that the state has a longstanding history of attempting to redress workplace inequalities between men and women, and New York's bill called wage disparities between men and women "unjust").

199. Id. See supra Part.II.B.3.

200. S.B. 358, 2015 Leg., Reg. Sess. (Cal. 2015); A06075, 201st Leg., Reg. Sess. (N.Y. 2015); S.2119, 189th Leg., Reg. Sess. (Mass. 2016). California, Massachusetts, and New York's bills all note that wage disparities disproportionately impact women, among other groups. California's bill notes that "persistent disparit[ies] in earnings still [have] a significant impact on the economic security and welfare of millions of working women and their families." S.B. 358, 2015 Leg., Reg. Sess. (Cal. 2015). New York's bill states that "[i]ndividuals are put at an economic disadvantage because of characteristics that bear no relationship to their job performance" and that "[s]uch disparities prevent maximum utilization of labor in the state economy." A06075, 201st Leg., Reg. Sess. (N.Y. 2015). 
gap. Such a perspective precludes the use of policy and adjudicative tools available to minimize the impact wage discrimination has on women, in particular working mothers and women living below the poverty line.

\section{The Wage Gap}

Decades of enforced federal and state pay equity laws have had limited impact on the wage gap between men and women. In 1979, fifteen years after Title VII was enacted - and the first year comparative wage data was collected-American women were only earning $63 \%$ of their male counterparts' salaries. ${ }^{201}$ In 1992 , that figure was $71 \%{ }^{202}$ The national wage gap closed only slightly by 2000 , as women's wages rose to $76 \%$ of men's wages over the next eight years. ${ }^{203}$ The most recent data from the Bureau of Labor Statistics show an even smaller increase over the last fifteen years. ${ }^{204}$ For "workers age 35 and older, women earned between 76 and 81 percent of what their male counterparts earned in 2014." ${ }^{205}$ In Kansas, the most recent data show that women fall on the lower end of the wage differential spectrum nationally: Kansas women earn about $71 \%$ of the salaries their male counterparts earn. ${ }^{206}$

It would be an oversimplification to attribute these disparities solely to the fact that women are paid less than men. Women's increased participation in the workforce over time and their more predominant representation in some job sectors over others complicate wage differential calculations. ${ }^{207}$ Further, economists have argued that eliminating wage differentials between men and women would be counterproductive because a greater number of women would enter

201. Wyman, supra note 22, at 25 .

202. Heidi I. Hartmann \& Stephanie Aaronson, Pay Equity and Women's Wage Increases: Success in the States, a Model for the Nation, 1 DUKE J. GENDER L. \& POL'Y 69, 69 (1994).

203. Wyman, supra note 22, at 25 .

204. U.S. Bureau of Labor Statistics, Highlights of Women's Earnings in 2014, BLS REPORTS 2 (Nov. 2015), http://www.bls.gov/opub/reports/womens-earnings/archive/highlights-of-womensearnings-in-2014.pdf.

205. Id. (noting also that "[f]or those under age 35, the earnings differences between women and men were smaller, with women earning 90 to 92 percent of what men earned").

206. National Partnership for Women \& Families, supra note 7, at 1. See also U.S. Census Bureau, 2015 American Community Survey 1-Year Estimates Table B20017: Median Earnings in the Past 12 Months (in 2015 Inflation-Adjusted Dollars) By Sex By Work Experience in the Past 12 Months for the Population 16 Years and Over with Earnings in the Past 12 Months, https://factfinder.census.gov/faces/tableservices/jsf/pages/productview.xhtml?pid=ACS_14_1YR_B 20017\&prodType $=$ table (last visited Mar. 20, 2017).

207. Wyman, supra note 22, at 25. See also Hartmann \& Aaronson, supra note 202, at 74-75 (noting that economists have argued that "improving women's opportunities" for employment is a more effective means of ensuring workplace stability for women). 
"already overcrowded occupation[s], yet leave more workers unemployed since the higher wages would be expected to reduce the number of jobs available.,"208

However, the data creates a persuasive case against the argument that women's choice of employment largely explains the wage gap. ${ }^{209}$ The disparity between men and women's wages exists regardless of the field in which women work, whether full-time or part-time, or the educational level women have attained. ${ }^{210}$ The gap between women and men's salaries ranges from women earning $71 \%$ of what men earn to $87 \%$ across the health care, social assistance, manufacturing, retail, and educational services industries. ${ }^{211}$ Women across the employment hierarchy within companies also consistently earn less than their male counterparts at the same levels. ${ }^{212}$ Women in management positions earn about 80 cents for every dollar men earn, and in office and administrative support positions, women earn about 87 cents on the dollar compared to men. ${ }^{213}$ The highest level of education a woman attains also does not put her above her male colleagues in terms of salary. ${ }^{214}$ For full-time employees, "women with doctoral degrees are paid less than men with

208. Hartmann \& Aaronson, supra note 202, at 74.

209. See Wyman, supra note 22, at 25 (noting that "[p]oor enforcement of equal pay laws is not the root cause of the continuing wage inequity between men and women" and that "[c]omplex social issues relating to women's roles in the home and workplace contribute to the failure of women to attain pay equity with men"). See also Nancy Levit, Keeping Feminism in Its Place: Sex Segregation and the Domestication of Female Academics, 49 U. KAN. L. REV. 775, 801-02 (2001) (acknowledging a 1999 study purporting "to show that women earn between ninety-five and ninetyeight cents to the male dollar and that the vast amount of wage disparities are due to women's career choices and voluntary assumption of family responsibilities" but arguing that "[t]his assumption of culturally or biologically embedded preferences has meant an institutional reluctance on the part of courts to evaluate the ways in which employer practices shape women's choices").

210. National Partnership for Women \& Families, supra note 7, at 2. See also U.S. Census Bureau, supra note 206, at 4-5.

211. National Partnership for Women \& Families, supra note 7, at 2. See also U.S. Census Bureau, 2014 American Community Survey 1-Year Estimates 2014, Table S2404: Industry by Sex and Median Earnings in the Past 12 Months (In 2014 Inflation-Adjusted Dollars) for the Full-Time, Year-Round Civilian Employed Population 16 Years and Over, https://factfinder.census.gov/faces/tableservices/jsf/pages/productview.xhtml?src=bkmk (last visited Feb. 23, 2017).

212. National Partnership for Women \& Families, supra note 7, at 2. See also U.S. Census Bureau, Current Population Survey,2015 Annual Social and Economic Supplement: Table PINC-06: Occupation of Longest Job-People 15 Years Old and Over, by Total Money Earnings in 2014, Work Experience in 2014, Race, Hispanic Origin, and Sex, https://www.census.gov/data/tables/timeseries/demo/income-poverty/cps-pinc/pinc-06.html (last visited Nov. 7, 2016).

213. National Partnership for Women \& Families, supra note 7, at 2.

214. Id. See also U.S. Census Bureau, Current Population Survey, Annual Social and Economic (ASEC) Supplement: Table PINC-03. Educational Attainment-People 25 Years Old and Over, by Total Money Earnings in 2014, Work Experience in 2014, Age, Race, Hispanic Origin, and Sex, https:/www.census.gov/data/tables/time-series/demo/income-poverty/cps-pinc/pinc-03.html (last visited Mar. 31, 2017) . 
master's degrees, and women with master's degrees are paid less than men with bachelor's degrees." 215

Scholars have argued that simply assuming what women's choices will be with respect to employment and education is detrimental because it ignores other possible tools to close the wage gap, such as through more effectively enforced statutes that lend themselves to more effective enforcement. ${ }^{216}$ With its current statutory language, Kansas is not making use of these tools to close its wage gap between men and women. Enacting more specific protections for women to pursue pay equity claims will benefit the state economically.

\section{The Wage Gap's Impact on the Economy}

Scholars and state legislatures alike have recognized the economic importance of using statutory tools to help close the wage gap. In particular, wage gap laws would have a substantial positive impact on working mothers, whose presence in the workforce has increased significantly over several decades. ${ }^{217}$ California and New York's legislatures specifically addressed their concerns about the economic consequences of the persistent wage gaps between men and women in their states. ${ }^{218}$ By improving statutory pay equity protections, Kansas can both address a significant social inequity and improve sectors of its economy.

Women's roles in the workplace-particularly as mothers in the workplace - have grown considerably since the $1970 \mathrm{~s},{ }^{219}$ about a decade after the Equal Pay Act was enacted. In 1975, 36\% of all families were two-earner households; in 1993, that percentage rose to nearly half of all families. ${ }^{220}$ That 1993 figure has remained consistent in the most recent Bureau of Labor Statistics data: $48 \%$ of all families are two-earner families. ${ }^{221}$ Today, women are the sole earners for just over $7 \%$ of families. ${ }^{222}$ Nearly $70 \%$ of all women with children under the age of 18 are working or seeking employment. ${ }^{223}$

\footnotetext{
215. National Partnership for Women \& Families, supra note 7, at 2.

216. See Wyman, supra note 22, at 25.

217. Hartmann \& Aaronson, supra note 202, at 70.

218. S.B. 358 § 1(b), 2015 Leg., Reg. Sess. (Cal. 2015); A06075, 201st Leg., Reg. Sess. (N.Y.

219. Hartmann \& Aaronson, supra note 202, at 70.

220. Id.

221. Bureau of Labor Statistics, Employment Characteristics of Families-2015 2 (Apr. 22, 2016, 10:00 AM), http://www.bls.gov/news.release/pdf/famee.pdf.

222. Id.

223. Id
} 2015). 
In Kansas specifically, because the state's women consistently earn less than men, they lose out on "more than $\$ 4.5$ billion every year due to the wage gap." 224 Policy groups have estimated that by closing the wage gap, Kansas women could afford about "81 more weeks of food for [their] famil[ies] (nearly two years' worth); [n]ine more months of mortgage and utilities payments; or [f]ourteen more months of rent." 225 Those statistics are placed into stark relief when juxtaposed with the fact that $31 \%$ of Kansas's women-led households live below the poverty line, where significant expansions in food and rent affordability are critical. ${ }^{226}$

By maintaining a system in which women are consistently paid lower wages than men across occupations, positions, and education levels, Kansas allows women to be placed at an economic disadvantage. Such a handicap leads to diminished financial resources for these women's families, particularly in women-led households and households operating on a sub-poverty-line income. In turn, women are unable to invest income into their families and communities and "lessen their reliance on public assistance programs." ${ }^{227}$ For instance, one study found that if a comparable worth or similar standard were put into place across the country, the poverty rate for working women would see a 40 to $50 \%$ decline. ${ }^{228}$

California and New York recognized the economic burden wage disparities place on their states, as evidenced by memoranda, committee notes, and justifications for their new pay equity statutes. ${ }^{229}$ The California state legislature noted that on average, women earned $84 \%$ of what men did in 2014, a few cents more than the national average of $78 \%$, and lost out on more than $\$ 33$ billion every year. ${ }^{230}$ The legislature expressed concern about the wage gap's "significant impact on the economic security and welfare of millions of working women and their families" and its contribution to "the higher statewide poverty rate among women." 231 In New York, the state legislature wrote that the $84 \%$

\footnotetext{
224. National Partnership for Women \& Families, supra note 7, at 1.

225. Id.

226. Id. For nationwide statistics, see also U.S. Census Bureau, American Community Survey 1Year Estimates 2014, Geographies: United States, Table DP03: Selected Economic Characteristics, https://factfinder.census.gov/faces/tableservices/jsf/pages/productview.xhtml?src=bkmk (last visited Nov. 7, 2016); Hartmann \& Aaronson, supra note 202, at 70 (noting that "financial contributions these employed women make to their families are important").

227. Hartmann \& Aaronson, supra note 202, at 70.

228. Id. at $70-71$

229. S. COMM. ON LABOR \& INDUS. RELATIONS, CONDITIONS OF EMPLOYMENT: GENDER WAGE DifFEREnTial, S. 358, 2015 Leg., Reg. SesS., at 3 (2015); N.Y. STATE ASSEMBly, MEMORANDUm IN SUPPORT OF LEGISLATION, A06075, 2015 LEG., REg. SESS. (2015).

230. S.B. 358, 2015 Leg., Reg. Sess. (Cal. 2015).

231. Id
} 
disparity between men and women's wages "prevent[s] maximum utilization of labor in the state economy." 232 The legislature noted that such differentials "put [individuals] at an economic disadvantage because of characteristics that bear no relationship to their job performance."233

These states are not alone in recognizing the economic potential in reducing or, eventually, eliminating the wage gap. California, New York, and other countries with stricter pay equity standards - such as Canada, Sweden, and Hong Kong - have all used the same rationale for adopting tools to close the wage gap. ${ }^{234}$ As the Associated Press reported, International Monetary Fund managing director Christine Lagarde has commented that "ensuring equal pay and economic opportunities for men and women boosts growth, promotes diversity, reduces economic inequality around the world and helps companies earn more." 235

Critics of strengthened pay equity statutes argue that negative consequences of such laws outweigh the aforementioned economic gains. They cite the costs of implementing pay equity programs, such as those associated with evaluating jobs to determine which positions have comparable worth and adjusting wages. ${ }^{236}$ They also critique interference with the private sector market as an undesirable consequence of enacting stronger pay equity laws. ${ }^{237}$ By increasing wages to achieve parity between the genders, critics argue, employers would attract a greater number of prospective employees but be forced to reduce the number of available positions because of higher salaries. ${ }^{238}$ Further, critics note that the potential for more women entering the marketplace could also result in lower wages for men and women because of employers' financial limitations. ${ }^{239}$

However, a study published in 1994 - about three decades after both the Equal Pay Act and Title VII were enacted-found that gradual introductions of pay equity changes "minimize potential negative effects." "40 Further, the study found "minimal" 241 to no effects of

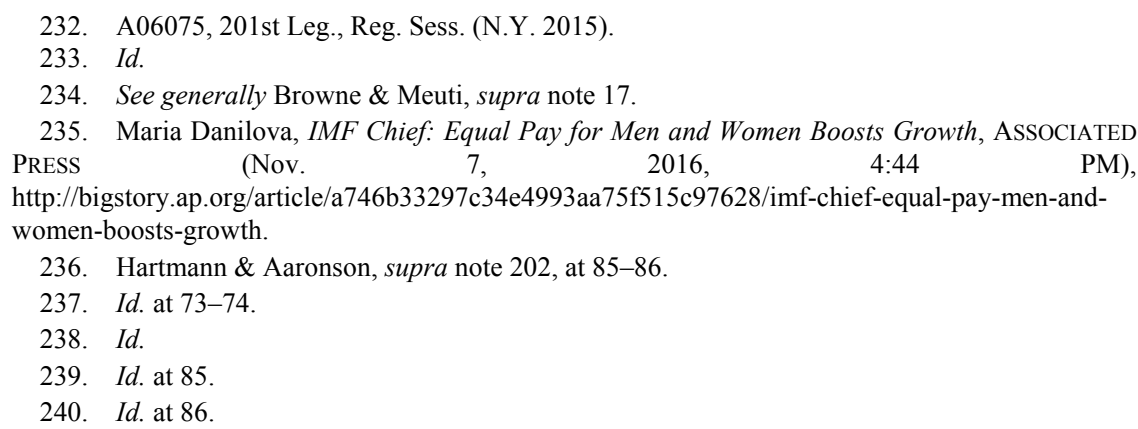


strengthened pay equity programs on depressed wages or declining employment in either the public or private sectors. ${ }^{242}$ To ensure Kansas does not take too drastic an approach to amending its pay equity statute, the state can gradually implement new provisions that the California, Massachusetts, and New York statutes model in three stages. As the following section discusses, Kansas should begin strengthening its pay equity statute by shifting from an "equal work" standard to a "comparable work" standard, more closely defining employer affirmative defenses, and establishing protections for wage transparency.

\section{B. Advocating for a New Pay Equity Regime in Kansas}

To facilitate the economic benefit that closing the wage gap can provide, Kansas should prioritize changes to its pay equity statute. An initial textual comparison between Kansas's pay equity statute and California, New York, and Massachusetts's statutes reveals an obvious gap between Kansas and those states deemed to be at the frontier of the trend toward broadening pay equity laws. The Kansas statute's "equal work" standard, its lack of detail in defining employers' affirmative defenses to wage disparity claims, and its non-existent prohibition on wage discussion limit the law's ability to adequately protect Kansas women and the state's general economic interest. Section 1 will discuss why Kansas should shift from an "equal work" standard to a "comparable work" standard. Section 2 will explain which affirmative defenses should be more narrowly defined and the ideal language the legislature should incorporate into Kansas's statute. Finally, Section 3 will outline the protections Kansas should establish to promote wage transparency.

\section{Shifting from "Equal Work" to "Comparable Work"}

Kansas should adopt a "comparable work" or "substantially similar work" standard analogous to the standards used in Massachusetts's and California's laws, respectively, because it allows for more uniform application and promotes economic growth. Kansas's current "equal pay for equal work" standard mirrors the Equal Pay Act's "equal work" language, ${ }^{243}$ which Congress did not intend to be interchangeably interpreted with a "comparable work" standard. ${ }^{244}$

241. Id. at 85 .

242. Id. at $85-86$.

243. Compare KAn. StAT. AnN. § 44-1205 (West 2000) with 29 U.S.C. § 206(d)(1) (2012).

244. Wyman, supra note 22, at 34 . 
An "equal work" standard places a "difficult burden"245 on plaintiffs that, even if carried successfully, has led to varying case outcomes depending on the court. ${ }^{246}$ Federal courts interpreting the Equal Pay Act have either construed it strictly or "pragmatic[ally]," 247 though most "have been reluctant to take a broad approach." 248 When courts apply the strict approach, they "often decline to find professional jobs as substantially equal" 249 and do not "compare professional jobs unless the jobs are fungible or mirror images of each other." 250 The Seventh and Eighth Circuits, following the strict interpretation of "equal work," also, unsurprisingly, have relatively low plaintiff success rates on claims brought under the Equal Pay Act. ${ }^{251}$

Courts following the pragmatic approach, however, are afforded greater breadth of interpretation and see higher plaintiff success rates. These courts "focus on whether the core functions or general purpose of the job are substantially similar and then determine if the additional tasks are significant enough to establish the jobs as unequal." 252 The pragmatic approach "takes into account the regulatory definitions of equal skill, effort, and responsibility to establish whether the overall job function is the same." "253 One scholarly survey of plaintiff successes in federal circuit courts "most receptive" to claims brought under the Equal Pay Act, such as the District of Columbia Circuit and the Sixth Circuit, found rates to be as high as $75 \%$ and $85 \%$, respectively. ${ }^{254}$ The Supreme Court's interpretation of the Equal Pay Act, handed down a decade after the statute's implementation, seems to align more closely with case outcomes under the pragmatic approach. ${ }^{255}$ The Court held that the law's purpose "is broadly remedial, and it should be construed and applied so as to fulfill the underlying purposes which Congress sought to achieve." 256

\footnotetext{
245. Yoshino, supra note 194, at 610. See also Wyman, supra note 22, at 33-34.

246. Yoshino, supra note 194, at 610-13.

247. Id. at $610-11$.

248. Wyman, supra note 22, at 33.

249. Yoshino, supra note 194, at 593.

250. Id. at 610 .

251. Id. at $611-12,611 \mathrm{n} .150$ (noting that plaintiffs bringing claims under the Equal Pay Act have a $24 \%$ success rate in the Seventh Circuit and a $39 \%$ success rate in the Eighth Circuit, both of which use the strict approach).

252. Id. at 594

253. Id. at 612 .

254. Id. at $611 \mathrm{n} .150$.

255. Corning Glass Works v. Brennan, 417 U.S. 188, 208 (1974).

256. Id. See also Yoshino, supra note 194, at 610-11; Wyman, supra note 22, at 31.
} 
Kansas has sparse case law interpreting its pay equity statute; however, language from one state case indicates that the statute's goal aligns closely with the pragmatic approach. In Mulford $v$. Department of Human Resources, a 1990 decision, the plaintiff was a state employee who claimed that a "position-to-position study" comparing job responsibilities and wages was required to determine whether the Kansas Department of Human Resources and Department of Administration, Division of Personnel Services, inappropriately lowered his salary because of a job reclassification. ${ }^{257}$ On appeal, plaintiff Verne Mulford challenged his salary decrease, arguing that such a change "must be based on substantial changes in the duties of [his] position" and that the department needed to compare his old and new positions. ${ }^{258}$ The court, discussing the governing Kansas statutes and Kansas Administrative Regulations, concluded that though the applicable law did not "use the phrase "equal pay for equal work," it did include a "goal of treating similar positions similarly." 259 This interpretation, though limited to administrative agency regulations, is analogous to the pragmatic approach federal courts have used when interpreting the Equal Pay Act.

The pragmatic approach offers greater protections for prospective plaintiffs without sacrificing employers' affirmative defenses. The approach affords courts discretion to evaluate several factors such as tasks, responsibilities, required skills, effort, and functions to determine whether jobs are similar enough to allow comparison. ${ }^{260}$ It "allows for flexibility" without removing the protections of employers' four affirmative defenses - seniority, merit, quality or quantity of production, and factors other than sex-that so many state statutes and federal statutes have codified. ${ }^{261}$ Language such as "comparable work" or "substantially similar work" eliminates the possibility of a strict interpretation - and its heavily negative consequences for prospective plaintiffs.

Adoption of a single "comparable work" or "substantially similar work" standard in Kansas would also facilitate the economic benefits of closing the wage gap. These standards would allow more women to

257. Mulford v. Dep’t of Human Res., 790 P.2d 957, 958-61 (Kan. Ct. App. 1990).

258. Id. at 959 .

259. Id. at 958-61. The court found, however, that the regulations did not explicitly mandate "equal pay for equal work." Id. at 961 . The court held that the agency director in question had discretion over "the decision of whether to do a position-to-position study." Id. In a situation where "a new [job] classification system was being put into place," the court concluded the agency was not acting "unreasonably, arbitrarily, or capriciously" when they 'refused to do a position-by-position study. Id.

260. Yoshino, supra note 194, at 612-13.

261. Id. at 612. See supra Parts II.A.1, II.A.2, II.B.1, II.B.2. 
survive summary judgment and pursue claims with greater possibilities of success. Because of the wider basis of comparison between jobs, plaintiffs will be afforded more opportunities to argue that their own jobs and the positions to which they are comparing their jobs are indeed substantially similar.

Further, though a "comparable work" or "substantially similar work" standard is broader than the "equal work" language in Kansas's current statute - and the Equal Pay Act - the former standard will also likely not bring about the negative consequences critics of strengthened pay equity laws fear. ${ }^{262}$ A significant number of federal courts are already interpreting the Equal Pay Act's "equal work" language to mean "substantially similar work" and are considering several factors to make job comparisons with minimal or no negative impacts such as higher unemployment or lower wages for all workers because of increased labor costs. ${ }^{263}$ Uniform application of a "comparable work" or "substantially similar work" standard-which are analogous to the "pragmatic approach" of interpreting the "equal work" standard-would not require a total reversal of common law interpretations of "equal pay for equal work" in Kansas.

\section{Narrower Definition of "Factor Other than Sex" Affirmative Defense}

Though the affirmative defenses of seniority, merit, and quantity and quality of production codified in federal and many state pay equity statutes, including Kansas's law, ${ }^{264}$ are relatively concrete, ${ }^{265}$ Kansas should clarify its fourth affirmative defense. That defense, "a factor other than sex," serves as a "catch-all defense" that has posed "the greatest problem for women pressing ... [Equal Pay Act] claim[s]."266 Because "a factor other than sex" has no further definition under the Equal Pay Act, Title VII, ${ }^{267}$ Kansas's pay equity statute, ${ }^{268}$ or several other state statutes, "courts' very general reading of [that affirmative defense] has reduced the effectiveness of the [Equal Pay Act]."269 Without careful definition of what constitutes "a factor other than sex," "[e]mployers only need to alter a job description along only one of the

\footnotetext{
262. See supra Part III.A.2.

263. Id.

264. See supra Part II.A.1, II.B.2, II.B.3.

265. Wyman, supra note 22, at 35.

266. Id.

267. See supra Part II.A.1, II.A.2.

268. See supra Part II.B.2.

269. Wyman, supra note 22, at 35 .
} 
four axes used for measuring value to make a 'man's job' different from a similar 'woman's job.",270

Kansas should adopt more specific definitions to bolster the fourth affirmative defense under its pay equity statute. The state should define "a factor other than sex" as "education, training, experience, or another factor that is reasonably job-related or furthers a legitimate business purpose. This factor may not be based on or derived from employees' sexes or cause a disparate impact based on sex." By enumerating job characteristics that employers must consider, plaintiffs can craft stronger claims and have a greater sense of predictability as their claims are adjudicated. Further, even before they file claims, plaintiffs will have a clearer understanding of those job characteristics that can result in wage differentials - and those that cannot.

The Paycheck Fairness Act and California, Massachusetts, and New York's statutes all attempt to solve the Equal Pay Act's definitional issues by enumerating specific factors employers can use as affirmative defenses under the "factor other than sex" umbrella. The Paycheck Fairness Act only allows employers to use education, training, experience, and other factors that are "job-related with respect to the position in question" or further a "legitimate business purpose" as factors other than sex that account for wage differentials between genders. ${ }^{271}$ California, Massachusetts, and New York's pay equity statutes each model a portion of the Paycheck Fairness Act's provisions: Massachusetts's law allows employers to use "education, training or experience" as factors other than sex to explain wage differentials "to the extent such factors are reasonably related to the particular job in question."272 California's law echoes this language and does not allow employers' affirmative defenses of factors other than sex to be "based on or derived from" employees' sexes - those factors must be job-related and "consistent with a business necessity."273 New York's statute prohibits factors other than sex from being based on sex and also requires such factors to be "job-related" and "consistent with business necessit[ies]."274 New York's law allows employees to rebut business necessity exceptions by showing three elements: (1) that the practice "causes a disparate impact on the basis of sex"; (2) that an alternative practice "would serve the same business purpose and not produce such

270. Browne \& Meuti, supra note 17, at 366.

271. S. 841, 109th Cong. (2005).

272. Act of Aug. 1, 2016, ch. 149, 2016 MASs. GEN. LAws § 105A(b)(i)-(iii), (v).

273. CAL. LAB. CODE $\S 1197.5(a)(1)(D)$ (West 2011).

274. N.Y. LAB. LAW § 194(1)(d) (McKinney 2009). 
differential"; and (3) the employer refused to adopt the practice. ${ }^{275}$ Kansas should draw from these state and federal examples to craft strengthened and specific language specifically defining "factors other than sex."

\section{Protections for Wage Transparency and Wage Discussions}

Kansas should adopt language from California, Massachusetts, and New York's statutes as well as key language from the Lilly Ledbetter Fair Pay Act to more effectively provide notice to employees about potential wage disparities and subsequent pay equity claims. By codifying prohibitions against employer restrictions on wage discussions and the Fair Pay Act's expanded statute of limitations for pay equity claims, employees will not be denied judicial recourse simply because they had no notice of subtle or silent discriminatory wage practices.

Simultaneously incorporating statutory provisions that protect both employers and employees will allow Kansas to balance interests. The state should specifically add language, as Massachusetts has done, protecting employees filing complaints, voicing opposition to discriminatory practices, testifying about wage disparity investigations, and discussing wages from employers' retaliation. ${ }^{276}$ However, as New York has done, Kansas should also allow employers to place reasonable limits on employee wage discussions and create an affirmative defense against wage discrimination claims if employees violate such appropriate limits. ${ }^{277}$ Such amendments would limit practical and logistical concerns of having no workplace guidelines governing wage discussions. However, they would also leave in place a fundamentally important catalyst for employees to hold employers accountable for compensation decisions and practices.

Wage transparency is a cornerstone of plaintiffs' wage discrimination claims. Justice Ginsburg's dissent in Ledbetter v. Goodyear Tire \& Rubber Co. highlighted the importance of wage transparency in providing employees notice that they may have viable pay equity claims. ${ }^{278}$ Such transparency depends on employees' abilities to discuss their wages with one another and with their employers without fearing retaliation. ${ }^{279}$ Transparency also bolsters employees' abilities to

275. Id.

276. See supra Part II.B.3.c.

277. See supra Part II.B.3.b.

278. Ledbetter v. Goodyear Tire \& Rubber Co., 550 U.S. 618, 645 (2007) (Ginsburg, J., dissenting).

279. Sandra W. Everitt, Can I See Your Paycheck? Achieving Pay Equity in Vermont Employer or Employee Responsibility?, 34-SPG VT. B.J. 33, 34-35 (2008) (noting that in 2004, a 
file timely claims, which the Lilly Ledbetter Fair Pay Act helped to facilitate by changing the point at which the statute of limitations for Title VII claims begins to toll. ${ }^{280}$ The tolling period can begin when a "discriminatory compensation decision or ... practice is adopted," "when an individual becomes subject" to such a decision or practice, or when that individual "is affected by application" of such a decision or practice. ${ }^{281}$ This law redefined and expanded statutes of limitation to allow older pay equity claims, or claims that have accumulated over time, to be viable, as Justice Ginsburg identified in her dissent. ${ }^{282}$

The Lilly Ledbetter Fair Pay Act and laws enacted in California, Massachusetts, and New York work to improve wage transparency and give employees notice that potential pay equity claims exist. California, Massachusetts, and New York's pay equity statutes all prohibit employers from placing restrictions on employees' discussions of wages. ${ }^{283}$ These conversations facilitate notice that employees might be experiencing wage discrepancies and could start the tolling of one of the three statutes of limitations outlined in the Lilly Ledbetter Fair Pay Act if those provisions were adopted, which Massachusetts has done. ${ }^{284}$

\section{CONCLUSION}

Kansas's pay equity statute does little to protect the state's workers and economy. Federal law and proposed legislation as well as California, New York, and Massachusetts's more robust pay equity laws provide templates for Kansas to follow. Data and scholarly analyses of the impact existing pay equity laws have had over the past five decades demonstrate the need for continued strides toward closing the wage gap. The economic benefits of pay equity support the proposition that, more than fifty years after the enactment of the Equal Pay Act, pay equity remedies should be made more accessible to Kansas workers through statutory means.

\footnotetext{
survey "discovered that women either did not know what their male co-workers made and were afraid to ask, that they feared retaliation and job loss because of workplace cultures that discouraged discussion about wages, or that they were forbidden to discuss their wages because they had signed wage non-disclosure agreements. In one instance, after a male co-worker disclosed his higher wage and the female co-worker requested the higher rate, the employer granted the increase but then fired the male worker for disclosing his wage.").

280. See supra Part II.B.3.

281. 42 U.S.C. $\S 2000 \mathrm{e}-5(\mathrm{e})(3)(\mathrm{A})$ (2012).

282. Ledbetter v. Goodyear Tire \& Rubber Co., 550, 648-49 U.S. 618 (2007) (Ginsburg, J., dissenting).

283. See supra Part II.B.3.c.

284. Id.
} 